\title{
Pyramid Capitalism:
}

\section{Cronyism, Regulation, and Firm Productivity in Egypt}

Ishac Diwan/Philip Keefer/Marc Schiffbauer

\author{
CID Working Paper No. 291 \\ Revised, March 2015
}

(C) Copyright 2015 Diwan, Ishac; Keefer, Philip;

Schiffbauer, Marc; and the President and Fellows of

Harvard College at Harvard University 


\title{
Pyramid Capitalism:
}

\section{Cronyism, Regulation, and Firm Productivity in Egypt}

\author{
Revised draft, March 2015 \\ Ishac Diwan (Paris School of Economics) \\ Philip Keefer (Inter-American Development Bank) \\ Marc Schiffbauer (World Bank)
}

\begin{abstract}
Using an original database of 469 politically connected firms under the Mubarak regime in Egypt, we explore the economic effects of cronyism. Previous research has shown that cronyism is lucrative. We address numerous questions raised by this research. Do crony firms receive favorable regulatory treatment? They do: connected firms are more likely to benefit from trade protection, energy subsidies, access to land, and regulatory enforcement. Does regulatory capture account for the high value of connected firms? In our sample, regulatory capture as revealed by energy subsidies and trade protection account for the higher profits of politically connected firms. Do crony firms hurt aggregate growth? We identify the growth effects of the entry of politically connected firms by comparing detailed 4-digit sectors where they entered, between 1996 and 2006, and sectors that remained unconnected. Crony entry into new, modern and previously unconnected sectors slows aggregate employment growth and skews the distribution of employment towards less productive smaller firms.
\end{abstract}

Acknowledgements: We are grateful for the research assistance of Sahar Hussain and for very helpful comments received by participants in seminars at the World Bank, the Harvard Kennedy School, the ERF Conference 2014 in Cairo, and the CSAE Conference 2014 at Oxford University.

Disclaimer: The findings, interpretations, and conclusions expressed in this paper are entirely those of the authors and do not necessarily represent the views of the World Bank, its Executive Directors, or the countries they represent, nor of the Inter-American Development Bank, its Board of Directors, nor the countries that they represent. 


\section{Introduction}

A wealth of research has documented the value of political connections, giving rise to two important questions. To what degree is the value of connections related to regulatory privilege? And what is the effect of privilege on aggregate economic growth? Using novel data from Egypt, we document that connected firms are more profitable and larger; and they enjoy special regulatory treatment across a wide range of policy and regulatory domains. We then go beyond previous research and show that the profit advantage that they enjoy is entirely explained by their regulatory privileges; and the entry of connected firms into sectors where they were previously absent reduces aggregate growth and leads to a more skewed distribution of employment towards less productive smaller firms.

Past research has found that politically connected firms benefit from privileged access to credit. We document benefits across a numerous other regulatory domains: they are more likely to benefit from subsidies, trade protection, access to land, and biased regulatory enforcement. Prior research has also left open the possibility that connected firms could be more profitable because they are better protected from government predation, not because they receive regulatory privileges. We show that privileged access to energy subsidies and trade protection accounts for the higher profits of politically connected firms.

Finally, and most importantly, past research has raised the question of whether the high value of connected firms comes at the expense of aggregate economic growth in the sectors where connected firms operate. Our data allow us to examine the impact of cronyism on the growth of the detailed 4-digit sectors that cronies entered compared to the sectors that they did not enter. We observe the variation in market entry of politically connected firms between 1996 and 2006, a period that coincides with the extension of cronyism into several more modern, younger industries - those that one would expect should grow fastest. Instead, the entry of politically connected firms into these new, previously unconnected sectors slows their aggregate employment growth relative to sectors that remained unconnected. The data also point to a mechanism that is consistent with theory: slower employment growth after the entry of connected firms stems from an increase in the skewness of the employment distribution towards small and micro firms; these firms are less productive in Egypt, suggesting that the entry of connected firms in a sector increases the misallocation of resources across firms in the sector.

The paper is organized as follows. Section 2 reviews our contributions to the literature on cronyism. Section 3 reviews the modalities and evolution of cronyism in Egypt. Section 4 details our sample of connected firms and describes their characteristics. Section 5 asks whether the connected firms profited disproportionately from protection and subsidies and evaluates their relative efficiency compared to unconnected firms. Section 6 examines whether the presence of connected firms reduced the dynamism and growth opportunities of the rest of the economy. Section 7 provides direct evidence that cronyism reduces aggregate sector economic growth. The final section concludes with a discussion of the broader implications of the results.

\section{What do we know about cronyism?}

The literature on political connections addresses three concerns: the extent to which political connections are valuable; the ways in which politically connected firms receive policy favors; and the degree to which political connections affect firm performance, as well as economic development more 
broadly. Past research has tended to address only one or another of these concerns. This paper addresses all of them.

Beginning with Fisman's (2001) seminal contribution, scholars have systematically documented the value of political connections by investigating movements in the stock prices of connected firms relative to other firms when the probability of a change in political leadership increases. Like Fisman, Chekir and Diwan (2012) use an event study methodology and apply it to Egypt. They estimate the value of political connections for 22 connected, publicly traded firms to be about 13 to 16 percent of the firms' value, close to Fisman's estimates of the value of connectedness in Suharto's Indonesia.

The fact that the value of connected firms falls when leadership change threatens has three different interpretations. First, regime change could reduce the value of these firms if the firms benefit from policy distortions that would be reversed by new leaders. . Second, the threat of regime change could reduce the value of politically connected firms if they are better able than other firms to defend themselves from predation by the current - but not the next - government, but otherwise receive no policy advantages. Third, the simple fact of their connectedness may leave firms open to retribution by a new regime, a threat that would again reduce their value. In this paper, we address these ambiguities by examining a wide range of mechanisms that support the first interpretation.

A large literature has also addressed this ambiguity by identifying specific mechanisms through which firms may gain from political connections (e.g., Cull and Xu 2005 for China; Johnson and Mitton 2003 for Malaysia; Khwaja and Mian 2005 for Pakistan; Leuz and Oberholzer-Gee 2006 for Indonesia; Claessens, et al. 2006 for Brazil; and Faccio et al. 2006 based on cross-country panel data; see also Boubakri et al. 2010 and Goldman, et al. 2008). Most studies find that connected firms have better access to finance (higher debt). Some find that connected firms exhibit higher default rates and receive more frequent bailouts. Connected firms also enjoy tax advantages, greater market power and preferential access to government contracts. Boubakri et al. (2010) show that firms increase their indebtedness after establishing connections. Rijkers et al. (2014) examine the behavior of 214 Tunisian firms that were expropriated after the Jasmine Revolution because they were owned by members of the Ben-Ali family; these companies disproportionately benefited from FDI restrictions and licensing requirements.

Our paper advances this approach to research on cronyism in two ways. First, ours is the first analysis that demonstrates the breadth of regulatory advantages that connected firms receive: they disproportionately benefit from energy subsidies, trade protection, access to government land, and biased regulatory enforcement. ${ }^{1}$ Second, like Rijkers, et al. (2014), we focus almost entirely on the advantages enjoyed by politically connected firms that are clearly the result of explicit government decisions to grant them policy privileges that other firms do not enjoy.

Researchers have also asked how politically connected firms perform relative to nonconnected firms. Besides the advantages conferred by the privileges they receive over non-connected firms, connected firms could also be facing additional costs related to their need to repay the favors

\footnotetext{
1 Kroszner and Stratmann (1998) show that political influence affects regulatory protection in the United States, but influential firms are far from "cronyistic". Rather, legislators simply pay more attention to, and are more susceptible to lobbying by, economic sectors that are important in their districts.
} 
to politicians, such as creating more jobs than business conditions merit, or simply financing the electoral campaigns of their political allies.

Most researchers have found that connected firms perform better: the advantages of connectedness were higher than the costs (Roberts (1990) and Goldman et al. (2009) for firms in the U.S. and Ramalho (2003) for firms in Brazil). Authors taking a more historical approach (Ferguson and Voth (2008) looking at Nazi Germany and Haber and Maurer (2007) examining connected firms under the dictatorship of Porfirio Díaz in México) have reached similar conclusions. Boubakri et al. (2009) document more clearly the causal path from connections to performance by finding that firms improve their financial performance after establishing connections.

A few studies show that connected firms end up with less value than comparable nonconnected firms. Bertrand et al. (2007) find that firms managed by connected CEOs in France create more jobs and pay higher wages than non-connected firms. Using a large cross-country panel, Faccio $(2007,2010)$ concludes that connected firms perform worse than unconnected firms on a rate of return basis. Her results leave open the possibility that the connected firms in her sample have higher values because they also receive implicit bail-out guarantees, which are reflected in the value of the firm but not in their return on assets. ${ }^{2}$

We are able to show, using a larger sample of connected firms, not only that connected firms in Egypt were larger, more profitable, and received a broad range of government privileges, but also that their performance differences can be entirely accounted for by these government privileges. Moreover, our paper is the first that begins to show the broad development effects of cronyism: that it retards the growth opportunities of unconnected firms and suppresses aggregate job creation.

\section{Cronyism in Egypt}

The Middle East literature on Arab capitalism contains rich analyses of how autocrats allowed business elites to dominate the business sector in exchange for support for the regime. Qualitative research has documented barriers to entry that excluded opponents and provided privileges to a small coterie of friendly capitalists (Henry and Springborg 2010, Owen 2004, Heydeman 2004, King 2009, World Bank, 2009, World Bank, 2014). In Egypt, observers argue that cronyism thrived in the "businessmen" cabinet headed by Ahmad Nazif from 2004 to 2011 (Kienle 2004; Sfakianakis 2004). In Tunisia, the Ben Ali and Trabelsi families monopolized business opportunities and even expropriated the real estate and business holdings of wealthy elites. Similar stories about favoritism and insiders abound in Syria, Libya, Yemen, and Algeria, where political cronies seem to control large chunks of the private sector (Albrecht 2002; Alley 2010; Haddad 2012; Tlemcani 1999).

In Egypt, the government erected barriers to entry even as it engaged in economic liberalization. In the early 2000s, the country's policies shifted towards accelerated privatization and financial sector and trade reforms. However, connected firms were able to capture the new opportunities created by liberalization: massive housing projects and construction, tourism at coastal areas, the oil and gas sectors, the banking sector, and telephony, as well as local distribution of international consumer brands (Roll, 2010; Loewe, 2013; Ahram Online, various issues).

3 Chekir and Diwan (2015), in their study of a smaller sample of connected firms in Egypt, also find that connected firms were less efficient than other large stock market firms in Egypt. Their excess value, however, stemmed instead from the value of implicit bail-out guarantees provided to them. 
Government decisions were key in all of these areas - tourist resorts and housing projects were built on formerly government-owned land to which connected families had privileged access. Investments in oil and gas required government approval; new banks or factories in specific manufacturing sectors such as cement required government licenses. Connected firms could leverage their connections to ensure that international brands seeking to enter Egypt would grant them exclusive distribution licenses, shielding connected wholesale \& retail firms from competition. Our data indicates that politically connected firms are, in fact, especially concentrated in tourism (hotel \& restaurants, tour operators, transport), real estate, construction, wholesale \& retail trade, mining, finance, business services, and manufacturing sectors (see Table A1 in the Appendix).

Connected businessmen were well-placed to influence these decisions: they were not only personally well connected with the political leadership, but they themselves also occupied important post in government, the ruling party, parliament, and various influential boards and committees (Demmelhuber and Roll, 2007; Roll, 2010; Loewe, 2013). Trials of leading businessmen since the Arab Spring have shed light on land appropriation at below-market prices; the manipulation of government regulations to stifle competition; subsidized borrowing from state banks; and privileged access to subsidized energy and state procurement contracts (Ahram Online, various issues).

\section{Firm Data}

To examine the economic effects of insider privilege, we need a dataset of politically connected firms under the Mubarak regime in Egypt, and information about firm performance and the regulatory environment confronting firms. Following Fisman (2001), we created a list of politically connected businessmen (all were men) by interviewing managers of banks and private equity funds, lawyers and NGOs (e.g., anti-corruption organizations). At the same time, similar to Faccio (2007), we pruned the list to include only those businessmen who had influential political posts in the ruling party or in the government, or whose immediate family members did. Unlike Faccio, we also had sufficient information to identify long-term friends of the Mubarak family; these were also identified as connected businessmen. ${ }^{3}$

As in Faccio (2007), our approach identifies political connections using "ex ante" criteria: businessmen who had the direct means to tilt economic policymaking in their favor at the national level and thus faced a conflict of interest between maximizing their profits and shaping national economic policies. ${ }^{4}$ Other research has relied on "ex post" criteria, lists of owners of confiscated assets after a regime change. The "ex post" approach may yield fewer false positives (the identification of cronies who, in fact, never exercised their proximity to the president for economic advantage). However, the approach may also yield false negatives: some old regime cronies may establish close

\footnotetext{
3 Out of the 32 PC businessmen, 18 were ministers or led the policy committee in the National Democratic Party (NDP) after 2001 and controlled two-third (307 of the 469) of the firms we ultimately identified as connected. The policy committee is a crucial body at the NDP and is the source for most of the government's actions (Demmelhuber and Roll, 2007; Roll, 2013). The other 14 businessmen are either long-term friends of Hosni Mubarak from military times or cofounders of a large investment bank partly owned by a Cyprus registered company owned by the Mubarak family.

4 We use a more stringent criteria than Faccio (2007) by focusing on businessmen who have influential political posts either in the government (e.g., ministers) or in the ruling national democratic party (e.g., leading a policy committee). In contrast, Faccio (2007) focusses on businessmen that are a member of parliament in their corresponding country and thus have only indirect (lobbying) influence over economic policymaking at the national level.
} 
relationships with new leaders and not have their assets confiscated. In any event, about half of those on our list of cronies also appear on lists of confiscated assets after the change of regime.

We then matched the list of politically connected businessmen to firms listed on the Cairo stock exchange. The Orbis database includes this information on the board members, managing directors, or major shareholders of 854 firms that are currently or were formerly traded on the exchange. 5 The names of 32 businessmen identified in step one matched unambiguously the names of board members, managers, or major shareholders of 104 firms. Since these 104 firms could be holding companies or investment funds, we further used the Internet to identify the names of all subsidiaries (up to two tiers) and then matched these subsidiaries with firms in the Orbis database.

This process identified 469 firms that are unambiguously controlled, directly or indirectly, by a connected businessman. Of these firms, 47 have a politically connected businessman as a general manager (CEO), 140 have at least one connected board member, and in 334, at least one connected businessman or firm was unambiguously identified to have an ownership stake. In addition, in 172 firms a private equity fund owned by at least one politically connected businessman had an ownership stake. $^{6}$

It is likely that the effects of political connections vary according to the incentives of politically connected individuals to exercise them. Those closely involved with the operations of a firm are better able to identify the types of government privileges that would most benefit the firm. Hence, the ability of connected individuals to leverage connections may be strongest if they are the CEO of the relevant firms. However, company owners have unambiguously high-powered incentives to obtain such privileges. Hence, the incentives of politically connected individuals to exercise their connections are greatest if they own at least part of their companies. Both ability and incentives may be weakest for firms where the politically connected have indirect ownership of a connected firm, through politically connected private equity firms. ${ }^{7}$ We investigate these issues below.

Our analysis compares the performance and regulatory exposure of sectors according to the concentration of cronies in the sector. This type of analysis is feasible only if there is substantial dispersion in the intensity of political connections across sectors. The first column of Table 1 disaggregates politically connected firms by the type of political connection; the second column lists the number of 4-digit economic sectors that have at least one PC firm with each particular kind of connection. Firms in Egypt operate in 320 non-farm, non-government 4-digit ISIC Rev.4 sectors. Politically connected firms are active in about half of these.

\footnotetext{
5 Many large firms were listed at stock exchanges in Egypt since gains from selling shares of listed companies are exempted from taxation. Reportedly, several politically connected firms exploited this legal tax loophole to avoid paying taxes for M\&A transactions; i.e., instead of selling firms directly, which is taxable, the transaction was conducted as an untaxed market transaction by first listing the company for sale at the stock exchange (Ahram Online, various issues).

6 Several politically connected private equity funds list the firms of which they hold equity on their website.

7 The same ranking applies if we consider that information asymmetry matter among different type of ownerships; i.e., the connected CEO should be most effective in lobbying for privileges as he has the most accurate knowledge of firm specific information and cost structures; the connected owner has less information but still more than the connected private equity investor. Of course, it also matters how "close" the political connection to the businessman is, however, we do not have information to distinguish between different types of connections as all connected businessman are considered to have first tier political influence over regulations and their implementation.
} 
Table 1: Type of political connection across firms and by 4-digit sectors

\begin{tabular}{|c|cc|}
\hline Type of PC firm & $\begin{array}{c}\text { Number of PC } \\
\text { firms of that type }\end{array}$ & $\begin{array}{c}\text { Number of 4-digit sectors (out } \\
\text { of 320) with at least one PC } \\
\text { firm of that type }\end{array}$ \\
\hline Any type of politically connected firm & 469 & 174 \\
Politically connected CEO & 47 & 50 \\
Politically connected owner & 334 & 148 \\
Politically connected private equity & 172 & 108 \\
\hline ownership & & \\
\hline
\end{tabular}

Having identified politically connected firms, we linked these to data on firm performance in order to compare their performance with that of unconnected firms within their sector. These data were taken from the Orbis database. It contains employment data for 20,000 establishments between 2003 and 2012; operating revenues for about 700 large establishments; and profits for about 400 large establishments.

To analyze the impact of political connections on aggregate employment growth, we take advantage of establishment census data from the department of statistics in Egypt (CAPMAS). The census includes employment and firm characteristics of over two million (non-farm) economic establishments in 1996 and 2006 (repeated cross-sections). It does not contain firm names and so cannot be used for inter-firm comparisons. However, we know which of the 320 non-farm, nongovernment (ISIC Rev. 4) 4-digit sectors have connected firms. ${ }^{8}$ We can therefore use the census data to estimate how total employment growth across detailed 4-digit sectors changes depending on the presence and entry of connected firms.

A similar exercise allows us to see if politically connected firms benefited from state-supported barriers to entry and energy subsidies. World Bank data (WITS) provides sector-specific information on non-tariff barriers to trade (NTMs). The UN reports data on the energy intensities of manufacturing industries - the industries that would benefit most from the massive energy subsidies available in Egypt during this period. We match these data to our data on the sectoral intensity of cronyism to see if 4-digit sectors with more politically connected firms benefit from more NTMs and are more energy-intensive (receive more energy subsidies).

Moreover, we test whether connected firms benefit from other types of regulatory capture. We do not know the specific regulatory experiences of connected firms relative to unconnected firms, but through World Bank Enterprise Survey (WBES) data, we can compare the regulatory environment across 4-digit sectors with more and fewer connected firms. We pool all available surveys for Egypt between 2004 and 2008 in order to maximize the representativeness of the perceived policy data at the sector level. Overall, the WBES data identify the regulatory environment perceived by more than 4,200 firms that were active in 90 (ISIC Rev. 3.1) 4-digit sectors. ${ }^{9}$ We then examine whether WBES

\footnotetext{
8 We exclude the following sectors as firm dynamics in these sectors are driven by the government and not the private sector in Egypt: public administration, education, health, arts (4-digit ISIC Rev. 4 codes larger than 8400).

${ }^{9}$ We exclude sectors for which we observe less than 4 firms leading to, on average, 38 firms per 4-digit sector.
} 
respondents from sectors with more connected firms experienced softer or harsher regulations than those from other sectors.

\section{Identification issues}

The overarching question in the literature on cronyism is whether politically connected firms extract policy advantages from government that allow them to earn higher rents at the expense of other firms, potentially reducing competitive pressures to increase productivity and, therefore, suppressing growth. Prior research has occasionally used exogenous variations in political connectedness, such as announcements of leader illness, to make inferences about the causal effects of political connectedness on firm value. ${ }^{10}$ In general, though, the research has relied on simple correlations between political connections and some subset of various possible consequences of connectedness.

In the first part of the paper, we lack, like most of the literature, an exogenous change in political connections with which to identify the causal effects of political connections on firm profits, firm size, or on various government regulations ranging from energy subsidies and trade protection to access to land and industrial zones. However, for the first time we are able to document such correlations across all of these. Moreover, we are able to show the robustness of these correlations to controls for firm characteristics, such as firm size or age, and fixed sector characteristics. These correlations do not establish the causal effect of cronyism: we cannot observe the counterfactual of what regulatory benefits might have flowed to these firms had they not enjoyed political connections.

Two arguments suggest a causal relationship, however. First, qualitative evidence indicates an increase in privileges for crony firms after the entry of connected businessmen into government (e.g., the establishment of non-tariff trade barriers after a prominent businessman became Minister of Industry and Trade in 2005). Second, it is unlikely that businessmen developed political connections as a consequence of increased contact with governments following independent policy shifts that favored their sectors.

In the second part of the paper, however, the data allow us to make stronger causal inferences. Many sectors exhibited no politically connected firms in 1996 (i.e., 145 4-digit sectors non-agriculture sectors). Between 1996 and 2006, however, politically connected firms entered into some of these sectors, but not others. We estimate the impact of political connections on aggregate sector growth by comparing previously unconnected sectors that experienced entry by connected firms with those that did not experience entry. Our identifying assumption is that crony firms did not enter new sectors with an (unobservable) lower growth potential. ${ }^{11}$ Such an unobservable correlation would lead to a bias in favor of our results (lower employment growth after the entry of crony firms into new, previously unconnected sectors). We present several pieces of evidence, however, that indicate that this scenario is unlikely including comparisons of the same sectors in other countries, showing no evidence that growth rates were lower in sectors where we observe crony entry in Egypt.

\footnotetext{
10 Event studies estimate the impact on firm value, thus discounted future profits, but they have to rely on small samples due the small number of traded firms on local stock markets.

11 We do control for observable differences in observable sector characteristics such as the average firm size, firm age, and broad sector dummies in the corresponding estimations.
} 
Many of our results below are based on differences between sectors with and without politically connected firms. This gives rise to the concern that the results hinge on a small number of sectors that happen to have politically connected firms. In fact, of the 320 sectors in our database about half (49\%) include connected firms (186 out of 372); 49 have at least one (33 sectors) and as many as 10 (one sector) firms with politically connected CEOs; 142 have at least one (57 sectors) and as many as 35 (one sector) firms with politically connected owners; and 165 have at least one (57) and as many as 35 (four sectors) firms with any form of political connection. Within manufacturing, where 41 percent of the connected firms operate, they are present in 58 percent of the 4-digit industries (73 out of 126).

Moreover, Tables A1 and A4 in the Appendix reveal substantial variation in the activities of connected firms. They operate in some more mature traditional 4-digit sectors, but not others. They also entered some modern sectors (e.g., manufacturing of batteries or computer programming services). These attributes of the distribution of connected firms across economic activities in Egypt facilitate the empirical identification of the impact of political connections on aggregate growth.

\section{Firm performance, connected versus unconnected firms}

If politically connected firms have policy advantages over unconnected firms, they should be able to accumulate larger market shares and scale than would otherwise be the case. Employment and revenues should therefore be greater. The Orbis data has employment data for around 20,000 establishments. On average, the 436 connected firms in this dataset 33 connected firms have no employment data) have 941 employees compared to 253 employees among the remaining establishments. Orbis consolidated revenue data, available for 678 firms, reveals that 67 connected firms with data had revenues of $\$ 172$ million, on average, four times higher than the 611 unconnected firms between 2003 and 2010.

In addition, protected from entry, the profits and profitability (profits/assets) of connected firms should be larger. Consolidated profits data, however, are available only for 288 firms. Of these, the 49 connected firms had average net profits that were 13 times higher than the profits of the remaining firms.

Table 2 presents the results of a more rigorous comparison of the size and profitability of connected and unconnected firms. ${ }^{12}$ The first column of Table 2 reports the unconditional performance differences of connected relative to unconnected firms. Along each of these dimensions, the differences between politically connected and unconnected firms are large in magnitude and statistically significant. Employment, revenue and profitability differentials persist when we restrict the comparison to politically connected and unconnected firms operating within the same 2-digit sectors (Column two of Table 2). The advantages of politically connected firms make them more profitable relative to other firms operating in the same sector. Thus, the performance differences are not specific to the (broader) sectors in which connected firms operate.

12 The relatively few firms that have data on revenues and profits in the Orbis database preclude the use of narrow definitions of political connectedness in the comparisons reported here. We therefore use the largest sample of politically connected firms. 
Table 2: Within-sector differences, politically connected (of any type) and other firms

\begin{tabular}{|lcccc|}
\hline & $\begin{array}{c}\text { PC vs. other } \\
\text { establishments }\end{array}$ & $\begin{array}{c}\text { PC vs. other } \\
\text { est., within } \\
\text { 2-digit } \\
\text { sector }\end{array}$ & $\begin{array}{c}\text { No. of } \\
\text { Politically } \\
\text { connected } \\
\text { establishments }\end{array}$ & $\begin{array}{c}\text { No. of other } \\
\text { establishments }\end{array}$ \\
\hline Ln(Employment) & $1.40^{* *}$ & $\begin{array}{c}1.02^{* *} \\
(12.39)\end{array}$ & 436 & 19,375 \\
Ln(Revenues) & $1.61 * *$ & $\begin{array}{l}1.59 * * \\
(6.27)\end{array}$ & 67 & 611 \\
Ln(Profits) & $(6.46)$ & $1.37 *$ & 49 & 239 \\
& $1.43^{* *}$ & $(1.73)$ & & 236 \\
Ln(Profits/Assets) & $1.98^{* *}$ & $2.17 * *$ & 47 & \\
& $(3.03)$ & $(3.29)$ & & \\
& & & & \\
\end{tabular}

Source: Orbis establishment database. Note: The establishment data are pooled across years (2003-2011). The first column reports the coefficient and $t$-statistic on the politically connected dummy variable from an OLS regression of the performance variable (e.g., $\ln ($ employment)) on the dummy variable, which is equal to 1 for politically connected establishments and 0 otherwise. In the second (third) column, we control for 2(4)-digit sector dummies. *, ** indicates that the coefficients are significant at the $5 \%, 10 \%$ level.

While we do not conduct a formal event study, we can still ask whether the profit advantage of connected firms vary with the strength of the Mubarak regime. This should be the case if connected firms were more profitable because of their connections, rather than some unobserved features of their entrepreneurial skill or products; and if our measures of the performance advantages of connected firms are reasonable. In fact, Figure 1 illustrates the predicted variation.

It compares the profits of firms with political connections relative to other (large) firms in the Orbis data and shows that the difference between the two was systematically related to the survival of the regime. The differential in profits was more than two times larger between 2005 and 2010 (significant at the 5 percent level). After the fall of the Mubarak regime on February 11, 2011, the large differential suddenly disappeared. ${ }^{13}$ The fact that the profit differential between connected and unconnected firms disappears shortly after the fall of Mubarak also corroborates the quality of our empirical measurement of politically connectedness in Egypt. ${ }^{14}$

\footnotetext{
13 Unfortunately, longer time series data for profits are not available in Orbis. The precision of estimated profit differential in 2003 and 2004 is low due to the few available observations.

14 We note that most of the regulatory privileges favoring connected firms (e.g., energy subsidies to industry or trade protection) are still in place until today. Thus, the decline in the profit differential for connected firms immediately after Mubarak's fall might reflect that other policy privileges (temporarily) disappeared (e.g., implementation bias - see below) or that the new regime at least initially made it generally more difficult for these businessmen to operate in Egypt.
} 


\section{Figure 1: The evolution of net profit differentials between connected and other firms}

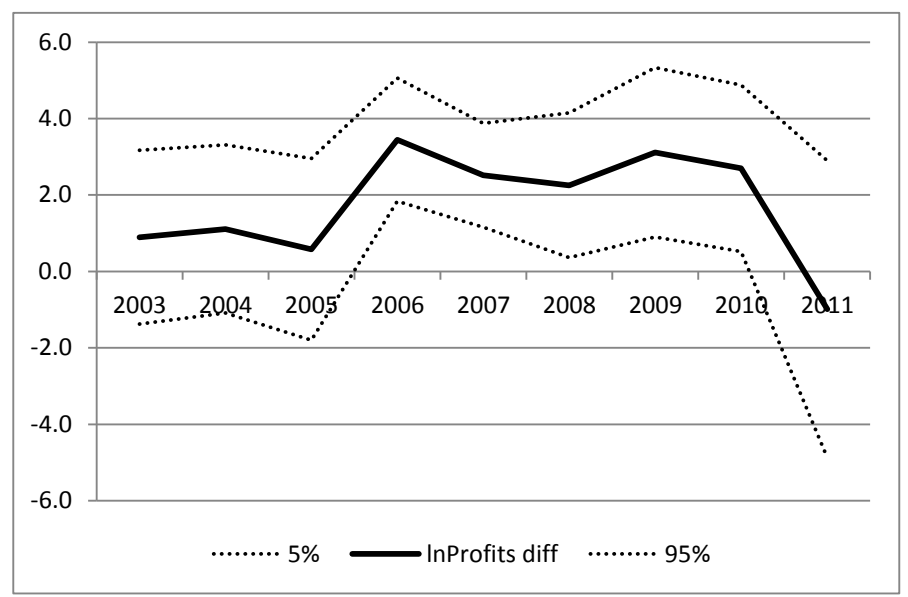

Source: Orbis establishment database. Note: The graph shows the differential in profits between politically connected and unconnected firms demeaned at the 2-digit sector level; the coefficient is derived from an OLS regression of net profits on 2-digit sector dummies as well as a dummy variable which is equal to 1 for politically connected establishments and 0 otherwise. The dotted lines show the $5 \%$ confidence intervals.

\section{The Policy Advantages of Political Connections in Egypt}

A substantial literature has focused on the advantages of connected firms with respect to access to credit: they enjoy favorable access to capital and they are more likely to be delinquent on their loans from state banks. In Egypt, as well, connected firms enjoyed privileged access to credit from state-owned banks. However, after the financial crisis at the end of the 1990s, policy reforms circumscribed the activities of state banks. In this section, we present evidence that, in the 2000s, connected firms enjoyed ample policy advantages in other areas, including protection from foreign competition and privileged access to energy subsidies or land. ${ }^{15}$ They also appear to have been less exposed to the arbitrary or predatory application of business regulations more generally. ${ }^{16}$

\section{Political connections and non-tariff trade barriers}

Although tariffs fell in Egypt at the end of the 1990s, the use of non-tariff technical import barriers increased. ${ }^{17}$ Building on data from a new World Bank database (WITS) measuring NTMs (Malouche et al., 2013), Figure 2 illustrates the decline in average weighted tariffs from about 16.5 percent in 1995 to 8.7 percent in 2009 - but also a steady and offsetting increase in NTMs. NTMs primarily included barriers to imports such as exclusive licenses requirements, rules of origin, or quality

\footnotetext{
15 These are only some of the potential regulatory channels that advantage connected firms. Others include the benefits of FDI restrictions for specific service sectors or fewer licensing restrictions (e.g., related to operating licenses), as well as implicit bail-out guarantees that facilitate borrowing, for which we do not have data.

16 These benefits accrued to connected firms despite the fact that, at the same time, Egypt was acclaimed for its efforts to reverse decades of state control of the economy. That is, even as the formal rules of the game appeared to improve (as measured, for example, by sharp improvements in "Doing Business" indicators), connected firms were, in the terminology of Hallward-Driemeier, et al. (2010), able to make "deals" with government to tilt the playing field in their favor.

17 The World Bank database on NTMs provides either the year when a particular NTM has been introduced or the latest year in which it is has been substantially revised. Unfortunately, the database does not distinguish between the two.
} 
controls (which leave scope for discretion) for imported products. As a result, Egypt had one of the highest NTM frequencies in the world in 2010 (Malouche et al., 2013).

Figure 2: The evolution of average (weighted) tariffs and NTMs on imports since 1

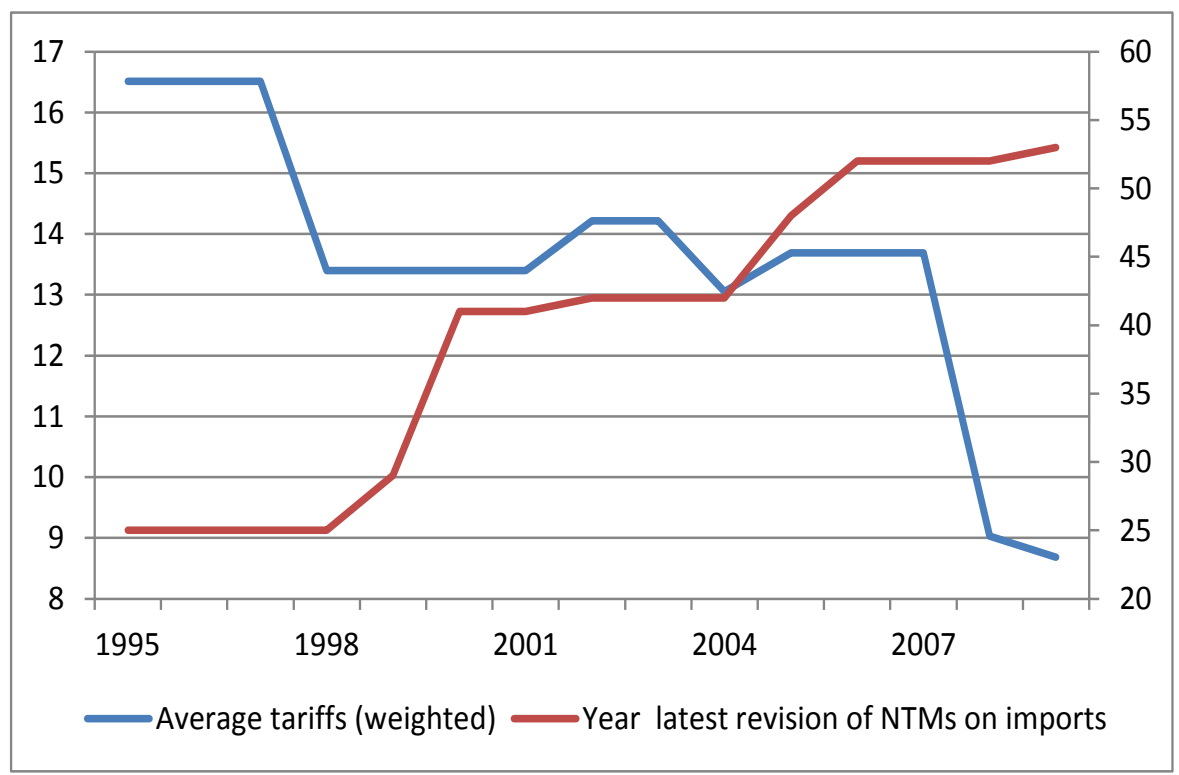

Source: WITS. Rate reflects most-favored nation tariffs. The NTMs data provides either the year when an NTM has been introduced or the latest year in which it is has been substantially revised.

Of the 53 different NTMs in place in Egypt in 2009, almost half (24) were introduced or amended around 2000 and 21 percent between 2005 and 2009. The first episode coincides with the period when several prominent businessmen started to head directorates for economics and business in the policy committee of the NDP which is the source for new economic policies and regulations of the government (Demmelhuber and Roll, 2007; Roll, 2013). NTM protection during the second episode were issued by the Ministry of Industry and Trade, which was headed at the time by a prominent businessman.

To test if these NTMs disproportionally benefitted politically connected firms, we match data on NTMs (at the 6-digit product level harmonized system classification) with census data (at the 4digit industry level) that contains information on all establishments in Egypt (about 2.5 million). ${ }^{18}$ The NTM measures are available for tradable goods, corresponding broadly to manufacturing and mining industries, or 147 sectors. Among the politically connected firms (broadly-defined) in our larger sample, 200 operate in at least one of these sectors. ${ }^{19}$

\footnotetext{
18 We convert the NTM data from 6-digit (HS Rev. 2002) product classification to the 4-digit industry ISIC Rev. 4 classification by using concordance tables from HS Rev. 2002 to ISIC Rev. 3 to ISIC Rev. 3.1 to ISIC Rev. 4, respectively. Several firms are operating in more than one 4-digit industry so that in total we have 230 industry-firm observations in manufacturing or mining.

19 Three politically connected firms are in two 4-digit ISIC Rev. 4 industries, Casting of non-ferrous metals and Forging, pressing, stamping and roll-forming of metal, which we had to drop from the NTM analysis since these industries have no equivalent HS (Rev. 2002) product code.
} 
Table 3 demonstrates in two ways that manufacturing and mining products sold by politically connected firms are more likely to be protected from import competition through NTMs. The first three columns list the fraction of firms with at least one political connection that are in sectors protected by at least one NTM. Across the three types of political connections, the three columns report whether this fraction is statistically different from the share of all firms that are in a sector protected by at least one NTM (listed in the fourth column). The second four columns list the fraction of products (four digit sectors) that exhibit at least one NTM, comparing products sold by at least one politically connected firm with products sold exclusively by non-connected firms.

This two way approach, analyzing the distribution of NTMs across firms as well as products, provides a robustness check, but also sheds light on the objectives of NTM protection. Not only were connected firms more likely to benefit from NTMs, but NTMs were also more likely to be granted to products manufactured by connected firms. This is a strong indication that NTMs were put in place primarily to protect politically connected firms from import competition.

In principle, if NTMs were targeted to products manufactured by connected firms, we should still observe the entry of both connected and unconnected firms into protected industries. If this were the case, though, connected firms would not be more likely to benefit from NTMs. However, the data indicate that they were more likely to benefit, indicating that NTMs tend to protect primarily connected firms relative to all other firms. Thus, the protection of products from import competition must have been coupled with additional barriers to entry into the protected industries. In fact, entry into several industries protected by NTMs (or the construction of additional factories in some industries) requires exclusive authorization requirements that have only been granted to a few (connected) firms in the past (such as in cement or steel). ${ }^{20}$

We make these comparisons for several types of NTMs. Most NTMs in Egypt are "Class B": license or registration requirements for importers, packaging requirements, regulations on production or distribution processes, traceability, and product-quality requirements. These restrictions are imposed on 65 percent (96 out of 147) of the 4-digit manufacturing industries. On average, these 96 industries confront 3-4 different Class B restrictions.

The seventh column of Table 3 indicates that at least one Class B NTM is imposed on 76 percent of all products sold by at least one (broadly defined) politically connected firm, but on only 55 percent of the products sold by all firms; the difference is statistically significant at the 1 percent level. More narrowly defined subsamples of politically connected firms demonstrate the same results (columns five and six): products sold by politically connected firms are significantly more likely to have at least one class B NTM. ${ }^{21}$

\footnotetext{
20 These are defined in the investment law in Egypt which is implemented by the General Authority for Investment (GAFI).

21 We also used a probit regression to test if non-tariff import barriers are more likely to be imposed in industries with politically connected firms controlling for the average firm size and age in the industry. The probability that a 4-digit industry is protected by at least one technical import barrier (NTM Class B) increases by 58 percent when a politically connected firm (broadest definition) is operating in that industry (the difference is statistically significant at the 1 percent level). The results are available from the authors upon request. We can only run the probit regression at the industry, not the firm level since we cannot identify the individual politically connected firms in the establishment census data.
} 
Table 3 also reports comparisons for other classes of NTMs. The second most common NTMs are sanitary restrictions (Class A). These affect 65 4-digit manufacturing industries, mostly in the food sector. When comparing the distribution of NTMs across connected and all firms, politically connected firms are more likely to be protected by Class A NTMs in two of the three comparisons. They are also more likely to be subject to price controls (Class F), which are imposed on 60 manufacturing industries (the differences are significant in two of the three firm level comparisons). Export-related measures (Class P) exist in only 16 manufacturing industries. In only one of the three comparisons are there significant differences between the two types of firms in this small sample.

Table 3: Percent of firms and products benefitting from Non-tariff Trade Measures

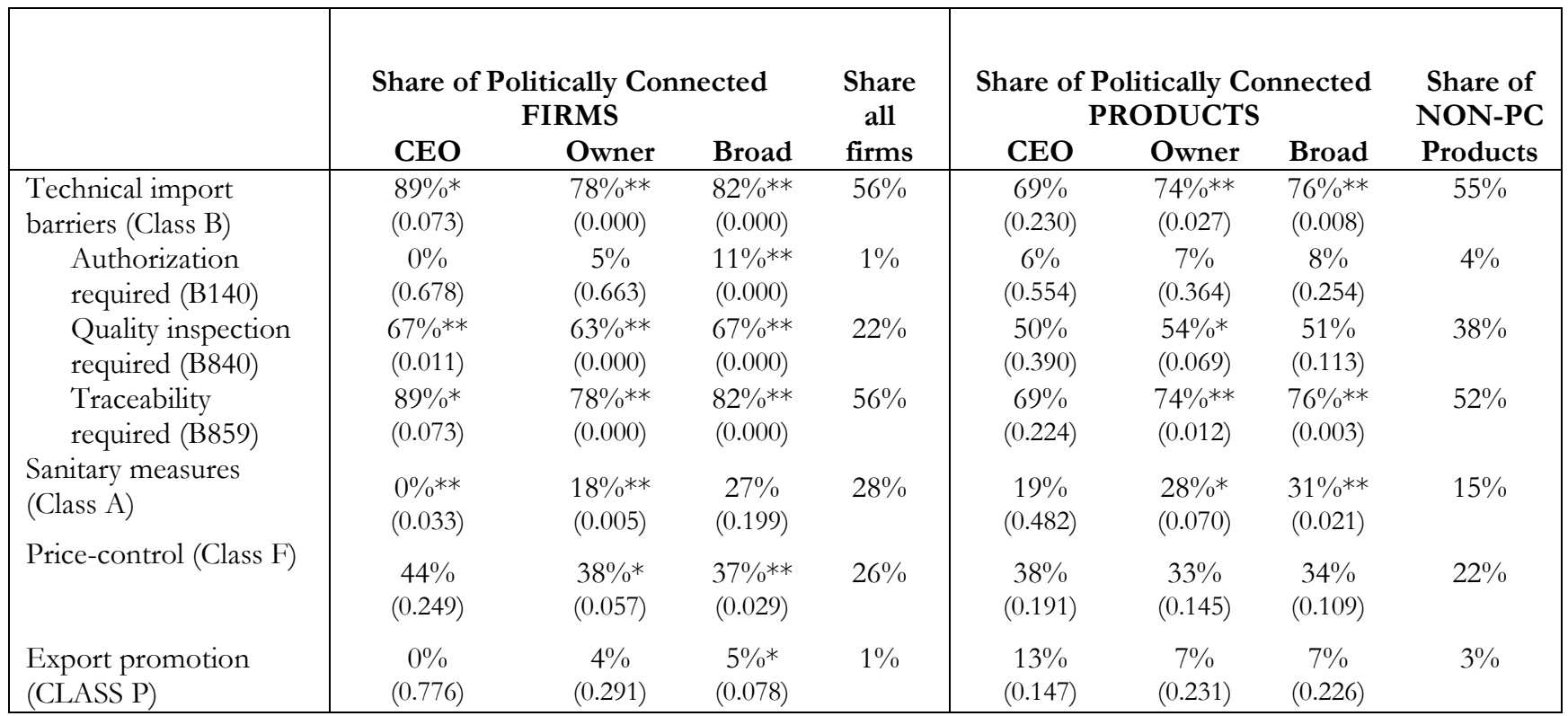

Source: WITS; establishment census data; sample of politically connected firms. Note: The significance level (p-values) for the statistical difference between politically connected firms or industries (columns 1-3 and 5-7) relative to all firms or industries (columns 4 and 8) is reported in parentheses; it is based on a Pearson Chi2-test. We use the Fisher-test (instead of the Chi2-test) to test for the significance in differences between PC and NOT-PC industries (and for firms also managed by connected CEOs) for NTMs CLASS P and CLASS B140 due to the small sample sizes. *, ** indicates that the coefficients are significant at the $5 \%, 10 \%$ level.

Malouche et al. (2013) highlight that the number of different NTMs imposed on a single product provides additional information on the intensity of trade protection. More NTMs are likely to offer greater protection from competition than fewer. Hence, if political connections matter for NTMs, we should also observe that the probability that a product is sold by a politically connected firm rises with the number of NTMs imposed on the product. The evidence in Table 4 demonstrates that this is the case for all three definitions of political connectedness.

Table 4 focuses on the most common type of Class B NTMs in Egypt (restrictions on imports). For example, 82 percent of connected firms of any type but only 27 percent of all firms are in sectors that are protected by at least two Class B NTMs. ${ }^{22}$ As in Table 3, we can demonstrate

22 The significance levels drop somewhat for the most restrictive measure of political connections (i.e., also managed by a connected CEO) due to the smaller sample sizes. The distribution of non-tariff technical barriers to import across all 
analogous results looking at products. For products protected by at least three NTMs (Class B), 71 percent of politically connected firms but only four percent of all firms benefit.

The results for Class B NTMs hold as the number of Class B NTMs rises, as the second, third and fourth rows demonstrate: the difference between the share of all firms or products that benefit from multiple NTMs and the share of connected firms or products increases as the number of NTMs rises. They are also mostly robust to even larger numbers of NTMs, but relatively few products are protected by more than four different NTMs.

In addition, the differences largely remain significant for narrower definitions of politically connected firms. The only exception relates to those NTMs that require imports to be authorized; however, overall, only few firms benefit from such exclusive import licenses. Thus, whether politically connected firms are defined as those with either a politically connected CEO or owner, they are more likely to benefit from Class B NTMs than unconnected firms.

Table 4: Politically connected firms are more likely to benefit disproportionately from NTMs the larger the number of NTMs in the product category

\begin{tabular}{|c|c|c|c|c|c|c|c|c|}
\hline \multirow[b]{2}{*}{ NTMs (class B) } & \multicolumn{3}{|c|}{$\begin{array}{l}\text { Share of Politically } \\
\text { Connected FIRMS }\end{array}$} & \multirow{2}{*}{$\begin{array}{c}\text { Share all } \\
\text { firms }\end{array}$} & \multicolumn{3}{|c|}{$\begin{array}{c}\text { Share of Politically } \\
\text { Connected PRODUCTS }\end{array}$} & \multirow{2}{*}{$\begin{array}{l}\text { Share of } \\
\text { NON-PC } \\
\text { Products }\end{array}$} \\
\hline & CEO & Owner & Broad & & CEO & Owner & Broad & \\
\hline $\begin{array}{l}\text { at least } 1 \text { per } \\
\text { industry }\end{array}$ & $\begin{array}{l}89 \% * \\
(0.073)\end{array}$ & $\begin{array}{l}78 \% \text { \%* } \\
(0.000)\end{array}$ & $\begin{array}{l}82 \% \text { ** } \\
(0.000)\end{array}$ & $56 \%$ & $\begin{array}{c}69 \% \\
(0.230)\end{array}$ & $\begin{array}{c}74 \%{ }^{* *} \\
(0.027)\end{array}$ & $\begin{array}{c}76 \% \text { ** } \\
(0.008)\end{array}$ & $55 \%$ \\
\hline $\begin{array}{l}\text { at least } 2 \text { per } \\
\text { industry }\end{array}$ & $\begin{array}{l}89 \% * \\
(0.073)\end{array}$ & $\begin{array}{l}78 \% \text { ** } \\
(0.000)\end{array}$ & $\begin{array}{c}82^{\circ} \% \text { ** } \\
(0.000)\end{array}$ & $27 \%$ & $\begin{array}{c}69 \% \\
(0.174)\end{array}$ & $\begin{array}{l}74 \% \text { ** } \\
(0.012)\end{array}$ & $\begin{array}{l}76 \% \text { ** } \\
(0.003)\end{array}$ & $52 \%$ \\
\hline $\begin{array}{l}\text { at least } 3 \text { per } \\
\text { industry }\end{array}$ & $\begin{array}{l}67 \% * * \\
(0.029)\end{array}$ & $\begin{array}{l}66 \% \text { ** } \\
(0.000)\end{array}$ & $\begin{array}{l}71 \% \text { \%* } \\
(0.000)\end{array}$ & $4 \%$ & $\begin{array}{c}50 \% \\
(0.390)\end{array}$ & $\begin{array}{l}60 \% \text { \%* } \\
(0.016)\end{array}$ & $\begin{array}{l}59 \% * * \\
(0.010)\end{array}$ & $38 \%$ \\
\hline $\begin{array}{l}\text { at least } 4 \text { per } \\
\text { industry }\end{array}$ & $\begin{array}{c}11 \% \\
(0.490)\end{array}$ & $\begin{array}{c}21 \% * * \\
(0.000)\end{array}$ & $\begin{array}{c}26 \% * * \\
(0.000)\end{array}$ & $3 \%$ & $\begin{array}{l}13 \% \\
(0.29)\end{array}$ & $\begin{array}{c}23 \% * * \\
(0.01)\end{array}$ & $\begin{array}{c}22 \% \text { ** } \\
(0.010)\end{array}$ & $7 \%$ \\
\hline $\begin{array}{l}\text { at least } 5 \text { per } \\
\text { industry }\end{array}$ & $\begin{array}{c}0 \% \\
(0.575)\end{array}$ & $\begin{array}{l}11 \% \text { ** } \\
(0.028)\end{array}$ & $\begin{array}{l}18 \% * * \\
(0.000)\end{array}$ & $3 \%$ & $\begin{array}{l}13 \% \\
(0.29)\end{array}$ & $\begin{array}{l}14 \% * \\
(0.09)\end{array}$ & $\begin{array}{l}15 \% * * \\
(0.053)\end{array}$ & $5 \%$ \\
\hline
\end{tabular}

Source is WITS; establishment census data; sample of politically connected firms. Note: The significance level (p-values) for the statistical difference between politically connected firms or industries (columns 1-3 and 5-7) relative to all firms or industries (columns 4 and 8) is reported in parentheses; it is based on a Pearson Chi2-test. We use the Fisher-test because of small samples to test for the significance in differences between PC and NOT-PC industries (and firms also managed by a connected CEO) for all comparisons with fewer than 5 NTMs per industry. *, ** indicates that the coefficients are significant at the $10 \%, 5 \%$ level, respectively.

\section{Politically connected firms and energy subsidies}

In 2010, subsidies to energy-intensive sectors accounted for 2.9 percent of Egyptian GDP or USD 7.4 billion. Connected firms disproportionately benefited from these. Based on the UN classification of the average energy intensity of different sectors, politically connected firms appear to be concentrated in energy- (and capital-) intensive manufacturing industries, such as base metals,

manufacturing or mining firms and industries suggests no systematic pattern to benefit manufacturing or mining industries with more firms. If anything more concentrated sectors benefitted disproportionally since 65 percent of all industries had some NTM protections but only 56 percent of all firms. 
cement, plastics, textiles, and ceramics (see Table A2 in the Appendix for the UN classification of sector energy intensity and Table A1 for the sector distribution of politically connected firms).

The empirical strategy to determine the advantages of politically connected firms with respect to energy subsidies is the same as with NTMs. Each firm is classified according to whether it belongs to a low, moderate, or high energy-intensive sector. ${ }^{23} \mathrm{We}$ then compare the distribution of politicallyconnected firms and all firms across 4-digit manufacturing industries with different energy intensities.

As with NTMs, we show that connected firms are more likely than unconnected firms to be in high, but not low or moderate, energy-intensive sectors, and that industries with politically connected firms are more likely to be high energy-intensive, but not moderate or low. The first four columns of Table 5 show that politically connected firms are significantly more likely to operate in energy-intensive industries. Of all connected firms (broadly defined), 45 percent operate in energyintensive industries, compared to only eight percent of all firms. The difference is significant at the one percent level and is larger for firms where the politically-connected individual is more closely tied to the firm (CEO or direct owner). In contrast, politically-connected firms are no more likely, or less likely, to be in less energy-intensive sectors.

Table 5: Percent of firms and industries benefitting from energy subsidies

\begin{tabular}{|c|c|c|c|c|c|c|c|c|}
\hline & \multicolumn{3}{|c|}{$\begin{array}{l}\text { Share of Politically Connected } \\
\text { FIRMS }\end{array}$} & \multirow{2}{*}{$\begin{array}{c}\text { Share } \\
\text { NON- } \\
\text { PC } \\
\text { firms }\end{array}$} & \multicolumn{3}{|c|}{$\begin{array}{c}\text { Share of Politically Connected } \\
\text { INDUSTRIES }\end{array}$} & \multirow{2}{*}{$\begin{array}{l}\text { Share of } \\
\text { NON-PC } \\
\text { Industries }\end{array}$} \\
\hline & CEO & Owner & Broad & & CEO & Owner & Broad & \\
\hline $\begin{array}{l}\text { High Energy-Intensive } \\
\text { Industry }\end{array}$ & $\begin{array}{l}55 \% * * \\
(0.000)\end{array}$ & $\begin{array}{l}49 \% * * \\
(0.000)\end{array}$ & $\begin{array}{l}45 \% * * \\
(0.000)\end{array}$ & $8 \%$ & $\begin{array}{l}22 \% * * \\
(0.024)\end{array}$ & $\begin{array}{l}66 \% * * \\
(0.000)\end{array}$ & $\begin{array}{l}81 \% * * \\
(0.000)\end{array}$ & $19 \%$ \\
\hline $\begin{array}{l}\text { Moderate Energy- } \\
\text { Intensive }\end{array}$ & $\begin{array}{c}36 \% \\
(0.115)\end{array}$ & $\begin{array}{l}28 \% * * \\
(0.000)\end{array}$ & $\begin{array}{l}30 \% * * \\
(0.000)\end{array}$ & $63 \%$ & $\begin{array}{c}8 \% \\
(0.421)\end{array}$ & $\begin{array}{c}33 \% \\
(0.340)\end{array}$ & $\begin{array}{c}48 \% \\
(0.674)\end{array}$ & $53 \%$ \\
\hline Low Energy-Intensive & $\begin{array}{c}9 \% \\
(0.196)\end{array}$ & $\begin{array}{c}23 \% \\
(0.214)\end{array}$ & $\begin{array}{c}26 \% \\
(0.173)\end{array}$ & $29 \%$ & $\begin{array}{l}10 \% \\
(0.731)\end{array}$ & $\begin{array}{c}34 \% \\
(0.362)\end{array}$ & $\begin{array}{c}43 \% \\
(0.115)\end{array}$ & $57 \%$ \\
\hline
\end{tabular}

Source: WITS; establishment census data; sample of politically connected firms. Note: The significance level (p-values) for the statistical difference between politically connected firms or industries (columns 1-3 and 5-7) relative to all firms or industries (columns 4 and 8) is reported in parentheses; it is based on a Pearson Chi2-test. We use the Fisher-test (instead of the Chi2-test) to test for the significance in differences between PC and NOT-PC industries with less than five connected firms of a specific type.

\section{Do connected firms have better access to land, industrial zones and credit?}

Similarly, the last four columns of Table 5 demonstrate that 81 percent of industries with at least one (broadly defined) politically connected firm, compared to only 19 percent of industries without a politically connected firm, are highly energy-intensive. The difference is significant at the one percent level. ${ }^{24}$ The difference is significant, as well, comparing industries with at least one firm

23 High energy-intensive industries account for 22 percent of all mining and manufacturing 4-digit industries, moderate energy-intensive industries for 37 percent, and low energy-intensive for 42 percent.

24 We also used a probit regression to test the probability that a sector is high energy intensive given connected firms are present controlling for the average firm size and age in the industry. We find that the probability for a 4-digit industry to be high energy intensive increases by 100 percent when a politically connected firm (broadest definition) is operating in that industry (the difference is statistically significant at the 1 percent level). The results are available from the authors 
with a politically connected owner or with at least one politically connected CEO. In contrast, once again, the share of less energy-intensive sectors with a politically connected firm, of any kind, is not different (statistically) from the share of these sectors that lack political connections.

Abundant anecdotal evidence indicates that politically connected firms in Egypt have superior access to land or credit. ${ }^{25}$ In the manufacturing sector, access to land includes access to industrial zones that offer benefits to occupants that competitors outside of these zones do not enjoy, including tax exemptions from corporate taxes and customs duties, better infrastructure, and more streamlined regulations. ${ }^{26}$ The evidence in this section demonstrates that firms in sectors with a higher intensity of political connections are more likely to have obtained land from the government or to have received it for free; to have obtained a bank loan; or to be located in an industrial zone. ${ }^{27}$

We do not have information for our sample of connected and unconnected firms about their firm-level experience with these variables. However, we are able to use well-known data from the World Bank Enterprise Survey (WBES) to build detailed 4-digit industry-level information on these. We can then ask whether WBES respondents from sectors with at least one connected firm are more likely to report that they received these benefits. We cannot be sure that those firms that report having received benefits are politically connected - WBES respondents are anonymous - but the fact that they are from sectors with more politically connected firms makes this more likely. ${ }^{28}$

The WBES data contain firm level information for each of these three variables. The first concerns an overtly government decision, whether the firm acquired land from the government: "Does your establishment own or lease the majority of its land? From whom have you gotten the land (people, government, for free, other)?" Industrial zones in Egypt are sponsored by the government and generally include subsidized infrastructure. Access to industrial parks is typically also a government decision. WBES asks about industrial parks, "Is the firm located in an industrial zone?" We also analyze responses to the WBES question, "Does your establishment currently have a loan from a financial institution?" Political connections affect access to credit in two ways. State-owned

upon request. Note that we can only run the probit regression at the industry but not the firm level since we cannot identify the individual politically connected firms in the establishment census data.

25 Reportedly, based on court disputes initiated after the fall of the Mubarak regime, the government not only sold the land to the politically connected, but also provided guarantees that it would connect the land with the necessary electricity, telecommunication, and transport infrastructure. This practice immediately increased the value of land, which the businessmen used as collateral to get bank loans that far exceeded the initial purchase value of the land (Ahram Online, various issues).

26 Industrial zones in Egypt include QIZs which guarantee firms duty and quota free exports to the U.S. Abdel-Latif and Nugent (2010) review the impact of QIZs in Egypt and find that large firms disproportionally benefit from the QIZ agreement: in the 17 industrial zones hosting QIZ factories 88 percent of exports are concentrated in firms with more than 500 workers. Textiles and garments account for 89 percent of QIZ exports, followed by plastics and chemicals.

27 Reportedly, the type of activities benefitting from tax exemptions in special economic zones was also demand driven; for instance, the list of sectors eligible for tax exemptions was expanded to include media companies after the construction of a new media complex (including the media company, hotels, theatres, etc.) by a politically connected businessman. The complex was declared a special economic zone shortly after, allowing him to benefit from tax exemptions (Ahram Online, various issues).

28 Moreover, while the WBES is a survey, it covers most large firms within a sector, which typically includes the connected firms in sectors where these firms are present. 
institutions are still important sources of private sector credit, so credit could have been a government decision that the politically connected could directly influence. In addition, the politically connected are likely to have a large advantage in securing private credit, if they enjoy implicit government guarantees.

As usual, we classify WBES firms according to their 4-digit industrial classification and aggregate firm reports of access to land, credit or location in an industrial park at the 4-digit sector level. Then, as in the analysis of NTMs and energy subsidies, we ask whether sectors with more politically connected firms have better access.

The WBES data include data from 3,040 firms in 91 4-digit (ISIC Rev. 3.1) manufacturing sectors. ${ }^{29}$ Out of 3,036 manufacturing firms, 1,431 reported acquiring land: 933 obtained the land from the government, 57 obtained it for free. In addition, 1,060 manufacturing firms are located in an industrial zone and 453 (out of 3,040) manufacturing firms reported a loan. Table A3 in the Appendix summarizes the descriptive statistics of the different perceived policy variables from the WBES, comparing manufacturing sectors with at least one politically connected firm with all other sectors (with zero connected firms). Firms in connected sectors are more likely to have acquired government land, to be located in an industrial zone, or to have a bank loan. It the following, we test more systematically for the impact of political connections on access to land, industrial zones, and bank loans.

In contrast to non-tariff barriers and energy subsidies, the information on firms' access to land, industrial zones, and credit is available at the firm level. This allows us to estimate probit regressions that assess whether the probability that a firm has access to land, industrial zones, or credit increases when it is operating in a 4-digit sector with a higher intensity of political connections (i.e., containing more politically connected firms):

$$
\text { Pol }_{i j}=\beta_{C} \text { connected }_{j}+\beta_{x} X_{i j}+\beta_{S} S+\varepsilon_{i j}
$$

The dependent policy variable $P o l_{i j}$ is a dummy variable for firm $i$ in the 4-digit sector $j$. It equals 1 if the firm bought land from the government or received it for free, it is located in an industrial zone, or it has a bank loan, respectively, and zero otherwise; connected measures the number of politically connected firms by type in the 4-digit sector $j . X_{i j}$ is a matrix of the firm level control variables (firm size and age), and $S$ is a matrix of 2 -digit sector dummies. ${ }^{30}$

29 Among the 91 manufacturing sectors, 59 have no politically connected CEOs, while 32 have at least one politically connected CEO; 26 have no politically connected owners, while the remaining 65 sectors have between one (18 sectors) and 35 (one sector) politically connected owners; and 19 have no politically connected firms of any kind, while the remaining 72 sectors exhibit between one (16 sectors) and 35 (two sectors) connected firms. In sectors with multiple connected firms, many of them are often owned by the same politically connected businessmen (or his family members).

30 All estimations include standard errors clustered at the 4-digit sector level to account for shocks common to firms in 4-digit sectors. 
Table 6: Political connections and firms' access to land, industrial zones, and credit by firm size

\begin{tabular}{lccc|ccc|ccc}
\hline \hline & \multicolumn{3}{c|}{$\begin{array}{c}\text { Acquired Land from } \\
\text { Government }\end{array}$} & \multicolumn{2}{c|}{ Located in Industrial City } & \multicolumn{3}{c}{ Obtained Bank Loan } \\
& CEO & Owner & Broad & CEO & Owner & Broad & CEO & Owner & Broad \\
\hline No. of PC firms & -.007 & $.021^{*}$ & $.015^{*}$ & .068 & $.041^{* *}$ & $.034^{* *}$ & $.139^{*}$ & $.032^{* *}$ & $.019^{* *}$ \\
& $(-0.11)$ & $(1.79)$ & $(1.75)$ & $(0.73)$ & $(2.32)$ & $(2.01)$ & $(1.74)$ & $(2.54)$ & $(2.21)$ \\
$\ln (\mathrm{empl})$ & $.337^{* *}$ & $.338^{* *}$ & $.337^{* *}$ & $.269^{* *}$ & $.271^{* *}$ & $.269^{* *}$ & $.195^{* *}$ & $.197^{* *}$ & $.195^{* *}$ \\
& $(16.4)$ & $(16.2)$ & $(16.1)$ & $(6.46)$ & $(6.50)$ & $(6.34)$ & $(9.32)$ & $(9.34)$ & $(9.29)$ \\
Age & $-.019^{* *}$ & $-.018^{* *}$ & $-.018^{* *}$ & $-.034^{* *}$ & $-.034^{* *}$ & $-.034^{* *}$ & $-.005^{* *}$ & $-.005^{* *}$ & $-.005^{* *}$ \\
& $(-8.93)$ & $(-8.90)$ & $(-8.91)$ & $(-8.84)$ & $(-8.84)$ & $(-9.04)$ & $(-2.66)$ & $(-2.64)$ & $(-2.66)$ \\
\hline No. of obs & 3,015 & 3,015 & 3,015 & 3,009 & 3,009 & 3,009 & 3,003 & 3,003 & 3,003 \\
Sector dummies & Yes & Yes & Yes & Yes & Yes & Yes & Yes & Yes & Yes \\
R-squared & 0.193 & 0.194 & 0.194 & 0.187 & 0.189 & 0.191 & 0.070 & 0.071 & 0.070 \\
\hline \hline
\end{tabular}

Source: World Bank Enterprise Survey (WBES) data for Egypt 2004-2008 and sample of politically connected firms. Note: Number of politically connected firms is the number, in our database, in each 4-digit sector. The three different types of connections (ordered here by their restrictiveness) are defined in Table 1. The number of employees (size) and firm age vary at the firm level. All regressions include 2-digit sector dummies. Standard errors are clustered at the sector level. *, ** indicates significance at the $10 \%, 5 \%$ level, t-statistics are reported in parentheses. 
Thus, (1) tests if, within the same 2-digit sector, WBES respondents in 4-digit industries with more political connections report greater access to government land, industrial zones and credit than those in related 4-digit industries without connections. Overall, we observe about 80 4-digit subsectors with available information on the policy variables in 23 2-digit manufacturing sectors. ${ }^{31}$

The results parallel the earlier NTM and subsidy findings. Table 6 shows that firms in politically-connected are more likely to report that they acquired land from the government; are located in an industrial zone; and obtained a bank loan. In only two cases, where politically-connected firms are identified on the basis of the political connectedness of the CEO, is the effect insignificant. The results are robust to controlling for 2-digit sector-specific effects, firm size and firm age. The specification is conservative, since controlling for firm size biases the impact of political connections downwards: connected firms are larger than unconnected firms in our sample and Table 6 shows that large firms are more likely to have access to land, industrial zones, and bank loans. ${ }^{32}$

These effects are also economically significant. For example, the second column indicates that with each additional politically connected firm owner in the 4-digit sector, the probability of obtaining land from the government increases by 2.1 percentage points. Thus, assuming linearity, firms in sectors with 10 crony firm owners are 21 percentage points more likely to have obtained land from the government than firms in sectors without crony firm owners. Similarly, firms in sectors with five crony CEOs are 60 percentage points more likely to have obtained a bank loan than firms in sectors without crony CEOs.

\section{Do connected firms disproportionately benefit from the enforcement of rules?}

Politically connected firms also used their connections to reduce their own regulatory burden and the threat of predatory behavior by government officials relative to the burden and threats faced by their competitors. To see this, we again employ the WBES data, which contains firms' assessments of the burden imposed by various government policies and regulations. The WBES also asks firms for objective information, such as the time it takes to get a construction permit. Again, we supplement the WBES data with our information on the number of political connected per 4-digit manufacturing industries.

Following Hallward-Driemeier et al. (2010), we also examine within-industry variations of firm reports of the regulatory environment. If cronies influence regulator behavior, crony firms in a sector should report a lower regulatory burden; for instance, crony firms should report lower waiting times to obtain permits and more predictable regulatory behavior than firms in other sectors. At the same time, non-crony firms that compete with cronies in the same sector should have the longest waiting times if connected businessmen use their influence to discriminate against their direct competitors.

\footnotetext{
31 Our findings are generally stronger when we allow for comparisons of political connections across 4-digit sectors in different manufacturing industries (not including 2-digit sectors dummies).

32 The size and precision of the estimated coefficients increases if we drop firm size from the control variables (the coefficients are significant in five out of six cases). The results are available from the authors upon request. The estimated coefficients also increase if we drop the 2-digit sector dummies; however, in this case, the results are also based on comparing, for example, a 4-digit textile industry with a 4-digit base metals industry instead of restricting the comparison to two different 4-digit textile (base metals) industries within the textile (base metals) sector.
} 
The (coefficient of) variation in regulatory responses within sector should therefore be greater in those sectors with more connected firms. 33

Against this background, we use two policy implementation indicators from the WBES as dependent variables in estimates of equation (1)). The first is firm responses to the question, "What was the actual wait duration (from the day you applied to the day you received the service or approval)?" The second is the coefficient of variation, within the 4-digit sector, of responses to this variable. ${ }^{34}$

Table 7: Political connections and variations in regulatory enforcement across firms

\begin{tabular}{lccc|ccc}
\hline \hline & \multicolumn{3}{c|}{ Waiting days for } & \multicolumn{2}{c}{ CoV (Construction Permit) } \\
& CEO & Owner & Broad & CEO & Owner & Broad \\
\hline No. of PC firms & $-40.9^{* *}$ & $-6.00^{* *}$ & $-4.13^{* *}$ & $.193^{* *}$ & $.037^{* *}$ & .023 \\
& $(-2.58)$ & $(-2.77)$ & $(-2.93)$ & $(2.65)$ & $(2.36)$ & $(1.52)$ \\
$\ln (\mathrm{empl})$ & 3.11 & 2.77 & 3.19 & .001 & .001 & .001 \\
& $(0.82)$ & $(0.74)$ & $(0.86)$ & $(1.03)$ & $(1.31)$ & $(1.15)$ \\
Age & $1.52^{* *}$ & $1.56^{* *}$ & $1.58^{* *}$ & -.013 & -.014 & -.014 \\
& $(2.57)$ & $(2.64)$ & $(2.65)$ & $(-0.97)$ & $(-1.06)$ & $(-1.03)$ \\
\hline No. of firms / sectors & 986 & 986 & 986 & 63 & 63 & 63 \\
Sector dummies & Yes & Yes & Yes & Yes & Yes & Yes \\
R-squared & 0.081 & 0.076 & 0.075 & 0.466 & 0.468 & 0.453 \\
\hline \hline
\end{tabular}

Source: WBES data for Egypt 2004-2008 and sample of politically connected firms. Note: PC indicates the number of politically connected firms varying at the 4-digit sector level. The three different types of connections (ordered here by their restrictiveness) are defined in Table 1. The number of employees (size) and firm age vary at the firm level. All firm level regressions include 2 -digit sector dummies. Standard errors are clustered at the sector level. $*$, ** indicates significance at the $10 \%, 5 \%$ level, t-statistics are reported in parentheses.

Table A3 in the Appendix summarizes the descriptive statistics among manufacturing sectors with at least one politically connected firm and all other sectors (with zero connected firms). It shows that firms in connected sectors wait, on average, 86 days less for their construction permit (broadest definition of connections). At the same time, the (coefficient of) variation is significantly larger in connected sectors pointing to the fact that some firms in connected sectors have access to fast-track

33 The coefficient of variation per 4-digit industry is the standard deviation divided by the mean; hence, this measure is independent of differences in the order of magnitudes in the mean (and standard deviation) across industries.

34 The WBES contains additional variables on government service delivery such as waiting time for an operating license, customs clearance, the number of inspections (by tax officials or municipalities), or the probability to get a government contract. The number of firms (and 4-digit industries) that report these services are, however, significantly smaller in our sample. For example, fewer firms export (and thus use customs services), or applied for government contracts or an operating license in the years of the survey. We find for all of these variables that the (coefficient of) variation of government services within 4-digit industries increases when politically connected firms operate in these industries. The corresponding coefficients are typically significant when we do not include 2-digit sector dummies. The significance levels typically drop when we additionally include 2-digit sector dummies, simply because, with fewer firms exposed to these regulations, the estimates are necessarily noisier. The results are available from the authors upon request. 
regulatory services while the other firms in the same sector have not. It the following, we test for this pattern more systematically.

The results are summarized in Table 7 . Firms in connected sectors report lower waiting times for construction permits (columns 2-4) consistent with the argument that connected firms are able to access fast-track regulatory services; the results are significant in all specifications. For instance, for the most conservative measure of political connections, each additional firm with a politically connected CEO reduces waiting time by 41 days (column two). Columns 5-7 show that sectors with more politically connected firms exhibit a significantly higher coefficient of variation in the waiting days for construction permits. Thus, while few firms in connected sector appear to have access fasttrack regulatory services, other firms have to wait significantly longer for the permits. We cannot directly identify the connected firms in the WBES. Still, it is likely that the connected firms obtain fast-track regulatory services while the non-connected firms competing with them in the same sector are discriminated against.

\section{Implications of cronyism for aggregate growth}

Politically connected firms in Egypt have higher revenues, more employees and higher net profits than unconnected firms in their sectors; they are disproportionately located in sectors that enjoy greater import protection and energy subsidies, more favorable treatment by regulatory agencies (lower waiting times for construction permits); and greater access to land and credit, including access to industrial zones. Together, these privileges endow connected firms with significant cost advantages compared to unconnected firms. Aghion et al. (2001) argue that these cost advantages lead to market structures that suppress sector productivity and, therefore, aggregate economic growth. This section reviews this argument and provides evidence consistent with the predictions of their model: the privileges enjoyed by connected firms account for their higher profits; and, in the next section, that the entry of connected firms into previously unconnected sectors slowed employment growth.

In industries that exhibit monopolistic competition, when competitors have comparable cost structures, they have incentives to pursue productivity growth. Each firm invests in the adoption of new technologies to reduce its costs and escape competition, at least temporarily. ${ }^{35}$ However, as Aghion et al. (2001) show, these incentives are attenuated when leading firms in the sector have exogenous cost advantages that cannot be overcome by trailing firms. ${ }^{36}$ The market leaders have little incentive to invest in innovation since they do not face competitive pressures to reduce their costs; the laggard firms are too far away from the frontier to bridge the cost gap and instead use vintage production technologies, focusing on local market niches to survive.

In this framework, political connections slow aggregate growth to the extent that two conditions are met. First, connected firms dominate a large number of sectors: we have shown that

\footnotetext{
35 They also show how perfect competition market structures can reduce the incentives for any innovation by reducing the discounted present value of rents from innovations (rent dissipation effect). Thus, they find an inverted U-shaped relation between competition and growth. They argue, however, that the negative part in the competition-growth nexus, whereby the rent-dissipation effect outweighs the escape competition effect, is less empirically relevant.

36 The framework is closely related to Parente and Prescott (2002). Aghion, et al. (2004, 20005) report empirical tests of predictions of the model with respect to the effects of product market competition and entry deregulation on growth (Aghion et al., 2005). We test additional implications of the model: whether sectors with politically-connected firms and their corresponding cost advantages exhibit lower entry and a skewed distribution of firm sizes in their sectors.
} 
they are present in half of the sectors in Egypt. Second, connected firms should receive large privileges (i.e., cost advantages exogenous to their productivity performance) that do not benefit unconnected firms. The policy privileges of the politically connected firms should drive a wedge between the prices of inputs and outputs that they confront compared to those faced by unconnected firms.

We test for the existence of such a wedge, showing that the policy privileges that connected firms receive account for their higher profit rates relative to unconnected firms. Specifically, two of the privileges enjoyed by connected firms, protection from import competition and energy subsidies, account for their higher profitability, just as they should if these firms exhibit large and exogenous cost advantages. To see this, we use the following specification to estimate whether connected firms are more profitable, i.e. have higher rents for a given pattern of input use, because their products are more frequently protected from import competition or because they absorb more energy subsidies.

$$
\begin{aligned}
& Y_{\text {ist }}=\beta_{B} \text { connected }_{\text {ist }}+\beta_{R} \text { Regulation }_{s t}+\beta_{B R} \text { connected }_{\text {sst }} * \text { Regulation }_{\text {st }}+ \\
& \beta_{X} \ln X_{\text {ist }}+\beta_{t} T+\varepsilon_{\text {ist }}
\end{aligned}
$$

$Y_{i s t}$ is the profitability (log of profits per assets) of firm $i$ in the 4-digit sector $s$ at time $t$. Connected is equal to one if firm $i$ enjoys political connections of any type in the 4-digit sector $s$. The variable regulation measures either the number of NTMs (Class B) protecting the firm's products in sector $s$ from import competition or a dummy variable equal to one if sector $s$ is high energy-intensive (according to UN classification) enabling access to energy subsidies in Egypt, and zero otherwise. $X_{i s}$ is a matrix of firm level control variables, and $T$ is a matrix of year dummies.

The analysis is based on Orbis firm survey data; this is the only database that allows us to identify individual connected firms. Profit and revenue data are available for 250 larger manufacturing and mining firms of which approximately 50 are politically connected by any type; our analysis is therefore focused on these 250 firms. ${ }^{37}$

\footnotetext{
37 We cannot include firm size as an additional control variable since the sample of firms that report profit data is small and many of these firms do not report their (consolidated) number of employees in Orbis. Thus, we only observe employment and profits jointly for eleven politically connected manufacturing firms and 40 firms overall.
} 
Table 8: NTMs and energy subsidies account for the higher profitability of connected firms

\begin{tabular}{|c|c|c|c|c|c|c|c|c|c|c|}
\hline Dependent Variable: & & & & & In(Profit & Asset & & & & \\
\hline PC broad firms & $\begin{array}{c}1.38^{* * *} \\
(2.30)\end{array}$ & $\begin{array}{l}1.36^{* *} \\
(2.30)\end{array}$ & $\begin{array}{c}-2.32 \\
(-1.19)\end{array}$ & $\begin{array}{l}1.56^{* *} \\
(2.37)\end{array}$ & $\begin{array}{c}.267 \\
(0.33)\end{array}$ & & & & & \\
\hline PC owner firms & & & & & & $\begin{array}{c}.428 \\
(0.58)\end{array}$ & $\begin{array}{c}.423 \\
(0.57)\end{array}$ & $\begin{array}{c}-4.96 * * \\
(-2.04)\end{array}$ & $\begin{array}{c}.491 \\
(0.62)\end{array}$ & $\begin{array}{c}-.677 \\
(-0.65)\end{array}$ \\
\hline NTMs & & $\begin{array}{l}-.144 \\
(-0.56)\end{array}$ & $\begin{array}{c}-.218 \\
(-0.78)\end{array}$ & & & & $\begin{array}{c}-.156 \\
(-0.62)\end{array}$ & $\begin{array}{c}-.019 \\
(-0.88)\end{array}$ & & \\
\hline PC broad * NTMs & & & $\begin{array}{l}1.03^{* *} \\
(2.40)\end{array}$ & & & & & & & \\
\hline PC own * NTMs & & & & & & & & $\begin{array}{c}1.50^{* * *} \\
(2.85)\end{array}$ & & \\
\hline High energy & & & & $\begin{array}{l}-.634 \\
(-1.04)\end{array}$ & $\begin{array}{c}-2.60 * * \\
(-2.73)\end{array}$ & & & & $\begin{array}{c}-.282 \\
(-0.44)\end{array}$ & $\begin{array}{l}-1.34 \\
(-1.09)\end{array}$ \\
\hline PC broad * High energy & & & & & $\begin{array}{c}4.55^{* * *} \\
(3.77)\end{array}$ & & & & & \\
\hline PC own * High energy & & & & & & & & & & $\begin{array}{c}3.57 * * \\
(2.58)\end{array}$ \\
\hline Year Dummies & Yes & Yes & Yes & Yes & Yes & Yes & Yes & Yes & Yes & Yes \\
\hline Age & Yes & Yes & Yes & Yes & Yes & Yes & Yes & Yes & Yes & Yes \\
\hline No. of firms & 253 & 253 & 253 & 253 & 253 & 253 & 253 & 253 & 253 & 253 \\
\hline $\mathrm{R} 2$ & 0.061 & 0.061 & 0.063 & 0.063 & 0.094 & 0.044 & 0.049 & 0.062 & 0.050 & 0.066 \\
\hline
\end{tabular}

Source: Orbis database, yearly panel 2003-2011 and list of politically connected firms. Note: All regressions control for firm age and time dummies. PC broad refers to firms that meet any definition of connectedness. PC owner refers to firms whose owners are politically connected. The sample includes all firms from the Orbis data with available information for the corresponding variables. The standard errors are clustered at the year level accounting for the fact that the standard errors might be correlated for all firms in a given year due to year-specific shocks. *,** denote significance at the $10 \%, 5 \%$ significance level, respectively, t-statistics are reported in parentheses.

Table 8 shows that politically connected firms of any type are much more profitable than unconnected firms, even after accounting for differences in firm age. The second column reveals that the profitability differential remains after we control for the distribution of NTMs across sectors. However, column three indicates that the interaction of NTMs and politically connected firms across 4-digit industries accounts for the entire profitability differential. That is, politically connected firms of any type are significantly more profitable than unconnected firms if their products are protected from import competition but not otherwise. This result holds for both the broad definition of political connectedness and when connectedness is defined by the political connections of the owner. ${ }^{38}$ In the latter case, we also find that the few firms owned by connected businessmen that did operate in manufacturing sectors not (less) protected by NTMs have lower profits than unconnected firms in these sectors.

Results are similar when we account for the joint distribution of political connections and energy subsidies in high energy intensive industries. Connected manufacturing firms in high energy-

38 Note that all of the firms managed by a politically connected CEO with available profitability data operate in high energy intensive sectors and sell products that are protected by NTMs. Thus, we cannot repeat the exercise for this most restrictive sub-sample of connected firms. 
intensive industries are 4.5 or 3.6 times more profitable than unconnected firms in the same industries, using the broader and narrower definitions of connectedness, respectively.

These results strongly suggest that NTM protection from foreign competition and energy subsidies are targeted to crony firms and not available to unconnected firms. Qualitative evidence reinforces the difficulty that unconnected firms have in gaining access to these benefits. In the case of energy subsidies, firms require a government license to legally open a new (additional) factory in sectors that were heavy users of energy (steel, cement, etc.). This license was issued by the Ministry of Industry and Trade or the Ministry of Investment, where connected businessmen had a significant presence; the licenses had to be renewed annually. Politically connected firms were both more likely to get the license and less likely to be exposed to predatory behavior (i.e., the non-renewal of a license after they had undertaken large sunk investments). In the cement and steel sectors, only a few connected firms obtained the license guaranteeing access to the energy subsidies to heavy industry by 2010. In the case of NTMs, some of these measures also required explicit licenses to import specific intermediates from foreign manufacturers (e.g., in the automobile industry). ${ }^{39}$

\section{Implications of connectedness for employment growth}

In the following, we test directly if sector employment growth would have been higher in the absence of crony firms. The ideal counterfactual, the extent to which growth in the same sectors would have been higher in the absence of cronyism, is of course not observable: we could not randomly assign connected firms to sectors. Our data, however, include the years in which crony firms entered into new sectors. This creates a quasi-experimental setting that permits us to estimate a difference-indifference effect. That is, we can compare the change in employment in 4-digit sectors that crony firms entered with employment in sectors that they did not enter, holding constant fixed and unobserved sector characteristics that also affect growth.

In fact, there is ample evidence that the number and activities of politically connected businessmen increased between 1996 and 2006, a period that witnessed the intrusion of cronyism into more sectors and an intensification of state-business relations. ${ }^{40}$ Between 1997 and 2006, 46 politically connected firms entered 31 new 4-digit sectors that did not have connected firms initially (prior to 1997). These comprised a relatively diverse set of 14 service, 11 manufacturing, 3 utility, and 2 mining sectors. Moreover, we observe 114 4-digit sectors that were unconnected in 1996 and remained unconnected thereafter (were not entered by connected firms).

39 In some sectors we observe several crony firms which could, in principle, lead to competition among them. Instead, however, we observe a web of intertwined ownership structures and co-investments among crony firms. For instance, the six (ten) most intertwined businessmen together control stakes directly or indirectly in 240 (322) firms. In addition, 85 firms (18 percent) managed or owned by a connected businessman received significant investments from private equity funds controlled by other politically connected investors. Thus, collusion among crony firms is much more likely.

40 In particular, there is evidence that cronyism increased between 2000 and 2006 in the sense that several well connected businessmen took high political posts (e.g., becoming ministers) allowing them to steer economic policies directly in that period (Roll, 2010). For instance, Demmelhuber and Roll (2007) show that the number of businessmen in the Egyptian parliament increased from eight percent of total parliamentary seats between 1990 and 1995 to 50 percent between 2005 and 2010. Moreover, the presence of connected businessmen expanded to various new (previously not connected) sectors in that period (see Table A4 in the Appendix), in part also due to the first wave of privatizations (Skafianis, 2003). 
In this section, we first present the results of our difference in difference estimation, showing that the entry of connected firms slows employment growth. We then present data that supports our key identifying assumption that crony firms did not enter new sectors with an (unobservable) lower growth potential. ${ }^{41}$ Finally, we document a key mechanism, consistent with the theory, through which crony entry might have suppressed employment growth.

The estimation specifically tests whether employment growth declined over the ten year period between 1996 and 2006 in sectors that were initially unconnected (or open), but that experienced entry by crony firms. We use the following difference-in-difference estimation specification, whereby $\Delta Y_{s t}$ measures employment growth of the 4-digit sector $s$ between 1996 and 2006, PCEntry indicates the entry of politically connected firms between 1997 and 2007, NPC are sectors without crony firms before 1997, $X$ is a matrix of control variables (employment and age), and $S$ a matrix of sector dummies:

$$
\begin{aligned}
& \Delta Y_{s, 2006-1996}=\beta_{E} P C E n t r y_{s, 1997-2006}+\beta_{N} N P C_{s, 1996}+\beta_{E N}\left(P C E n t r y_{s, 1997-2006}\right. \\
& \left.N P C_{s, 1996}\right)+\beta_{X} X_{s, 1996}+S+\varepsilon_{s, 2006}
\end{aligned}
$$

We do not expect to observe adverse effects when connected firms enter into sectors that were already dominated by connected firms. Therefore, to capture the negative effects of entry by politically connected firms on aggregate employment growth, we focus on the coefficient $\beta_{E N}$, on the interaction of entry by the politically connected firm and a dummy variable capturing whether the sector was previously unconnected. ${ }^{42}$

Note that the coefficient on the entry of politically connected firms should be upwardly biased: in any regression the entry of connected firms mechanically contributes to sector employment growth. The aggregate effects of entry by connected firms on sector employment growth can only be negative, therefore, if their entry has a sufficiently adverse impact on the growth opportunities of unconnected peers.

Table 9 summarizes the findings of the difference-in-difference estimation. Columns two and three show the results for our most conservative measure, firms managed by a politically connected CEO. We find that the entry of crony firms into sectors that were previously unconnected has a significant, negative effect on employment growth in those sectors. The interaction terms are large and negative in all regressions, and statistically significant at the five percent level for the two more narrow definitions of political connections. ${ }^{43}$ The economic impact is large, implying as much as a 25

\footnotetext{
41 We do control for observable sector characteristics such as the average firm size, firm age, and broad sector dummies in the corresponding estimations.

42 We do typically not observe if other politically connected firms operated in these "unconnected" sectors but exited before 2006. Thus, we have to assume in this macroeconomic quasi-experiment that, if unobserved crony firms which were forced to exit before 2006 existed, they did not operate in these "unconnected" sectors. All available evidence, however, suggests that cronyism as well as policy privileges granted to the private sector expanded rather than declined between 1996 and 2006 (see Demmelhuber and Roll, 2007; Roll, 2010).

43 The results are robust if we only consider cases in which politically connected firms enter previously unconnected sectors before 2001. This effectively removes five 4-digit sectors where connected firms entered into unconnected sectors after 2001 from the difference-in-difference estimation. In fact, 38 (32) out of the 46 crony firms entered previously unconnected sectors before 2001 (1999). The results are available from the authors upon request.
} 
percent reduction in employment growth over the ten-year period 1996-2006. For the broadest measure of connectedness, which includes firms that received investments from connected private equity funds, the relevant coefficient of the interaction term is still negative and of comparable magnitude, but not significant at conventional levels.

These findings provide direct evidence that the growth impact of entry of connected firms is more than offset by their adverse impact on the growth opportunities of the majority of unconnected firms that stop growing or exit. In the case of Egypt, such large exogenous cost advantages are granted by energy subsidies, trade protection, access to prime land, biased regulatory enforcement, and other policy advantages. Even though these privileges might help the few benefitting firms to grow and create jobs, we show that the aggregate employment impact is negative due to the adverse effects of such policies on competition and thus the growth opportunities of the large majority of unconnected firms.

Table 9: Employment growth declines after politically connected firms enter initially unconnected sectors

\begin{tabular}{l|cccccc}
\hline \hline & \multicolumn{5}{c}{ Employment growth 1996-2006 } \\
& \multicolumn{2}{c}{ CEO } & \multicolumn{2}{c}{ Owner } & \multicolumn{2}{c}{ Broad } \\
\hline Entry PC & $32.2^{*}$ & $36.1^{* *}$ & 7.15 & 10.3 & 4.83 & 4.40 \\
& $(1.95)$ & $(2.09)$ & $(0.84)$ & $(1.24)$ & $(0.99)$ & $(0.77)$ \\
Not connected before 1996 & & -6.32 & & 15.1 & & -10.5 \\
& & $(-0.58)$ & & $(0.82)$ & & $(-0.67)$ \\
(Entry PC) * & & $-24.8^{* *}$ & & $-18.7^{* *}$ & & -14.96 \\
(Not connected before 1996) & & $(-2.17)$ & & $(-3.47)$ & & $(-0.97)$ \\
ln(empl) & $-.418^{* *}$ & $-.401^{* *}$ & $-.420^{* *}$ & $-.382^{* *}$ & $-.420^{* *}$ & $-.376^{* *}$ \\
& $(-2.44)$ & $(-2.17)$ & $(-2.37)$ & $(-2.16)$ & $(-2.34)$ & $(-2.62)$ \\
Age & 12.5 & 12.6 & 12.4 & 12.3 & 12.4 & 12.9 \\
& $(1.57)$ & $(1.56)$ & $(1.51)$ & $(1.53)$ & $(1.51)$ & $(1.55)$ \\
\hline No. of sectors & 224 & 224 & 224 & 224 & 224 & 224 \\
R-squared & 0.161 & 0.163 & 0.155 & 0.159 & 0.048 & 0.160 \\
Sector dummies & Yes & Yes & Yes & Yes & Yes & Yes \\
\hline \hline
\end{tabular}

Source: Establishment census data all non-agriculture, non-government sectors in 1996 and 2006 and sample of politically connected firms. Note: PC indicates the number of politically connected firms varying at the 4-digit sector level. The three different types of connections (ordered by their restrictiveness) are defined in Table 1. The number of employees (size) and firm age vary at the firm level. All firm level regressions include 1-digit sector dummies. Standard errors are clustered at the sector level. *,** denote significance at the $10 \%, 5 \%$ significance level, respectively, t-statistics are reported in parentheses.

\section{Evidence supporting identification}

Our interpretation of the results in Table 9 rests on the plausibility of our identification assumption, that politically connected firms did not disproportionately enter into intrinsically low growth sectors. On its face, it seems implausible that connected firms would avoid high growth sectors - the contrary seems more likely. In fact, observers argue that several sectors entered by connected 
firms exhibited high growth potential (see Table A4 in the Appendix and Skafianis, 2003; Roll, 2013; Loewe, 2013).

In addition, sectors with low growth potential should also have a significantly higher fraction of older firms. However, the share of young establishments in the unconnected sectors that cronies entered after 1996 was actually somewhat higher than in the unconnected sectors that cronies refrained from entering. For example, 50 percent of the establishments in unconnected sectors entered by connected firms were less than 10 years old and 28 percent were less than five years old. In the unconnected sectors that remained unconnected, 44 percent of establishments were less than 10 years old and 24 percent less than five years old.

This evidence is inconsistent with the argument that connected firms entered more mature sectors that were less likely to grow rapidly. Instead, it is more consistent of a bias in the opposite direction: connected firms may have entered into sectors with somewhat greater growth potential, and despite that these sectors experienced slower growth.

Table 10: Average annual value added growth rates (in percentage) of treatment and control group manufacturing sectors in all other countries between 1996 and 2006

\begin{tabular}{l|cccccc} 
& $\begin{array}{c}\text { All } \\
\text { Countries }\end{array}$ & $\begin{array}{c}\text { High } \\
\text { Income }\end{array}$ & $\begin{array}{c}\text { All } \\
\text { Developing }\end{array}$ & $\begin{array}{c}\text { MENA } \\
\text { Countries }\end{array}$ & $\begin{array}{c}\text { ECA } \\
\text { Countries }\end{array}$ & $\begin{array}{c}\text { LAC } \\
\text { Countries }\end{array}$ \\
\hline $\begin{array}{l}\text { Unconnected sectors in 1996 subsequently } \\
\text { entered by crony firms in Egypt }\end{array}$ & 2.28 & 1.50 & 3.08 & 2.67 & 4.94 & 1.94 \\
$\begin{array}{l}\text { Unconnected sectors in 1996 that remained } \\
\text { unconnected in Egypt }\end{array}$ & 1.12 & 0.77 & 1.47 & 0.46 & 2.66 & -1.61 \\
\hline Difference & $1.16^{* *}$ & $0.73^{* *}$ & $1.61^{*}$ & 2.21 & $2.28^{* *}$ & 3.55
\end{tabular}

Source: UNIDO (INSTAT4) and sample of politically connected firms in Egypt. Note: We use the broadest measure of political connections (see Table 1). The 4-digit new (previously unconnected) manufacturing sectors entered by crony firms after 1996 are listed in Table A4. Moreover, there are 31 unconnected sectors in 1996 that remained unconnected. "All Countries" includes all 104 countries with available data (excluding Egypt), "All Developing" 76 developing countries (excluding Egypt), "High Income" 28 high income countries, "MENA" all developing countries in the Middle East and North Africa, "ECA" all countries in Eastern Europe and Central Asia, "LAC" all countries in Latin America and the Caribbean (excluding small island states). $*$, ** denote that the difference in annual growth rates between the treat and control group sectors is significance at the 10\%, 5\% significance level (after controlling for 1-digit sector dummies).

Finally, we look at data from other countries to compare the growth record of the sectors entered by Egyptian connected firms and of sectors that they did not enter. If connected firms entered sectors with an inherently lower growth potential, we should observe those same sectors growing more slowly in other countries. In fact, in other countries where data are available, the sectors entered by connected firms in Egypt did not exhibit slower growth than the sectors that remained unconnected.

To show this, we need data on value added (or employment, investment, etc.) at the 4-digit sector level for manufacturing and service sectors between 1996 and 2006. UNIDO (INSTAT4) provides time series data on value added at the 4-digit sector level for manufacturing sectors for this time period. ${ }^{44}$ We use these data to compare the average growth rate of value added among countries

\footnotetext{
44 We did not find data for service sectors at the 4-digit sector level between 1996 and 2006. The exception is Jordan, which provides these data for several service sectors (see below).
} 
in other regions between 1996 and 2006 of the "treatment" group sectors - (4-digit manufacturing sectors that crony firms in Egypt entered after 1996 that were previously unconnected) with the average growth rate among these other countries of the "control" group sectors (4-digit manufacturing sectors that remained unconnected).

Table 10 shows that value added growth was, in fact, higher among all different country groups for the treatment group sectors. In addition, the difference in the average annual growth rates between the treatment and control group sectors is significant at conventional levels when using data for all countries, for all high income countries (which have the least market distortions), for all developing countries, and for all countries in Eastern Europe and Central Asia.

These findings suggest that our identifying assumption in Table 9, i.e. that crony firms did not enter new sectors with a lower growth potential, when estimating the impact of crony firm entry on aggregate sector growth is not violated. If anything, new sectors entered by crony firms in Egypt after 1996 appear to have had a higher growth potential, on average, than sectors that remained unconnected. This implies a bias against our findings since we nevertheless find that the actual growth rate after the entry of crony firms into these sectors was lower in Egypt. Our estimates are therefore likely to be a lower bound on the negative effects of cronyism on employment growth in Egypt.

Table 11: Average annual growth rates (in percentage) of treatment and control group manufacturing and service sectors in Jordan between 1996 and 2006

\begin{tabular}{|c|c|c|c|c|}
\hline & $\begin{array}{l}\text { Value } \\
\text { Added }\end{array}$ & $\begin{array}{l}\text { Investment } \\
\text { (in log } \\
\text { levels) }\end{array}$ & Wages & Profits \\
\hline $\begin{array}{l}\text { Unconnected sectors in } 1996 \text { subsequently } \\
\text { entered by crony firms in Egypt }\end{array}$ & 0.79 & 6.94 & 0.79 & 1.49 \\
\hline $\begin{array}{l}\text { Unconnected sectors in } 1996 \text { that remained } \\
\text { unconnected in Egypt }\end{array}$ & 1.17 & 5.44 & 0.85 & 1.56 \\
\hline Difference & -0.38 & $1.50 * *$ & -0.06 & -0.07 \\
\hline
\end{tabular}

Source: Department of Statistics Jordan and sample of politically connected firms in Egypt. Note: We use the broadest measure of political connections (see Table 1). We observe 13 new manufacturing and non-government service sectors entered by crony firms after 1996 and 44 sectors that remained unconnected. The 4-digit new (previously unconnected) sectors entered by crony firms after 1996 are listed in Table A4; data for Jordan in this period are not available for Other mining \& quarrying, Manufactures of whines, Manufacture of malt liquors, Manufacture of batteries, Manufacture of television \& radio receivers, Recycling of metal or non-metal waste, Collection, purification \& distribution of water, Wholesale of telecommunications parts, Inland water transport, Life insurance. *, ** denote that the difference in annual growth rates between the treat and control group sectors is significance at the 10\%,5\% significance level (after controlling for 1-digit sector dummies).

The results in Table 10 offer a compelling defense of our identification assumption, but the data exclude services. However, we were able to collect data for several 4-digit manufacturing and service sectors in Jordan between 1996 and 2006, and for a wider variety of sector performance variables. Results displayed in Table 11 reject the possibility that connected firms in Egypt entered slower-growing sectors. Treatment group sectors in Jordan exhibited greater investment, and no significant differences with the control group sectors with respect to value added, wages, or profits.

\section{Evidence on mechanisms: Political connections and the distribution of employment}

Crony entry can slow the growth of unconnected firms for three reasons. First, crony entry can affect the behavior of unconnected firms that remain in the sector. These firms might shrink due 
to fewer profitable investment opportunities. They might also stop growing in order to stay small enough to operate under the radar of their politically influential larger competitors. Second, crony entry might force faster-growing unconnected firms to exit these sectors. Third, the presence of connected firms might discourage new (potential) entrepreneurs from entering these sectors. We present evidence here that is consistent with the first of these mechanisms.

In more competitive economies, the policy advantages of connected firms should force unconnected firms to exit, the second mechanism. In Egypt, however, firm exit is low by international standards (Hussain and Schiffbauer, 2014). Instead, consistent with the first mechanism, employment is concentrated in (old) micro and small firms: establishment census data show that firms with fewer than ten employees account for 72 percent of aggregate employment (Hussain and Schiffbauer, 2014; World Bank, 2014). ${ }^{45}$ To see if this skewed distribution of firms is due to cronyism, we test whether the entry of crony firms skews the employment distribution of the sectors they enter towards smaller, less productive firms.

This distributional shift is consistent with the argument in Aghion, et al. (2001). They predict that in sectors dominated by firms with large and exclusive cost advantages, such as those granted to politically connected firms in Egypt, the firm size distribution should exhibit a large crony market leader and a potentially large number of small or (informal) micro firms using vintage technologies to serve local market niches. Thus, over time, a few large firms and many small firms should emerge in crony sectors. While the large crony firms create some jobs, the bulk of employment in these sectors will be concentrated in less productive, but more numerous micro or small firms, operating under the radar of their politically influential large competitors. In fact, in Egypt these firms are less productive (Hussain and Schiffbauer, 2014; World Bank, 2014)

Given our findings that political connections in Egypt translate into large policy privileges and the fact that the distribution of employment across firms in Egypt is skewed towards less productive micro and small firms, the size distribution of firms should become more skewed when crony firms enter previously unconnected sectors. The evidence presented below is consistent with this mechanism in Egypt.

Figure 1 compares the distribution of employment of initially unconnected sectors (see Table A4 in the Appendix) before (1996) and after (2006) the entry of crony firms. It shows that the distribution of employment became more skewed towards micro and small firms after the entry of crony firms; the difference in the distribution is significant at the one percent level (KolmogorovSmirnov test). These results indicate that the lower aggregate employment growth after the entry of crony firms into previously unconnected sectors originates from the decline of the (potentially large number of) unconnected firms in these sectors. Thus, these firms are not able to compete with their politically privileged peers; instead, they shrink or stop growing in order to stay small enough to operate under their radar. ${ }^{46}$ The evidence supports the conclusion that the cost advantages of

\footnotetext{
45 Consistent with these findings, our data suggest that the 469 politically connected firms only account for about seven percent of aggregate employment in Egypt.

46 Consistent with these results, we also find that the employment distribution in connected sectors is more right-skewed and exhibits a higher coefficient of variation (fatter tails) in employment. Likewise, the skewness and coefficient of variation in employment increased in crony sectors but declined in sectors that remained unconnected between 1996 and 2006. The results are available from the authors upon request.
} 
connected firms lead to a misallocation of resources (labor) in ways that are consistent with reduced productivity growth, as in Aghion et al. (2001). ${ }^{47}$

\section{Figure 1: Employment distribution before and after the entry of crony firms into previously unconnected sectors}

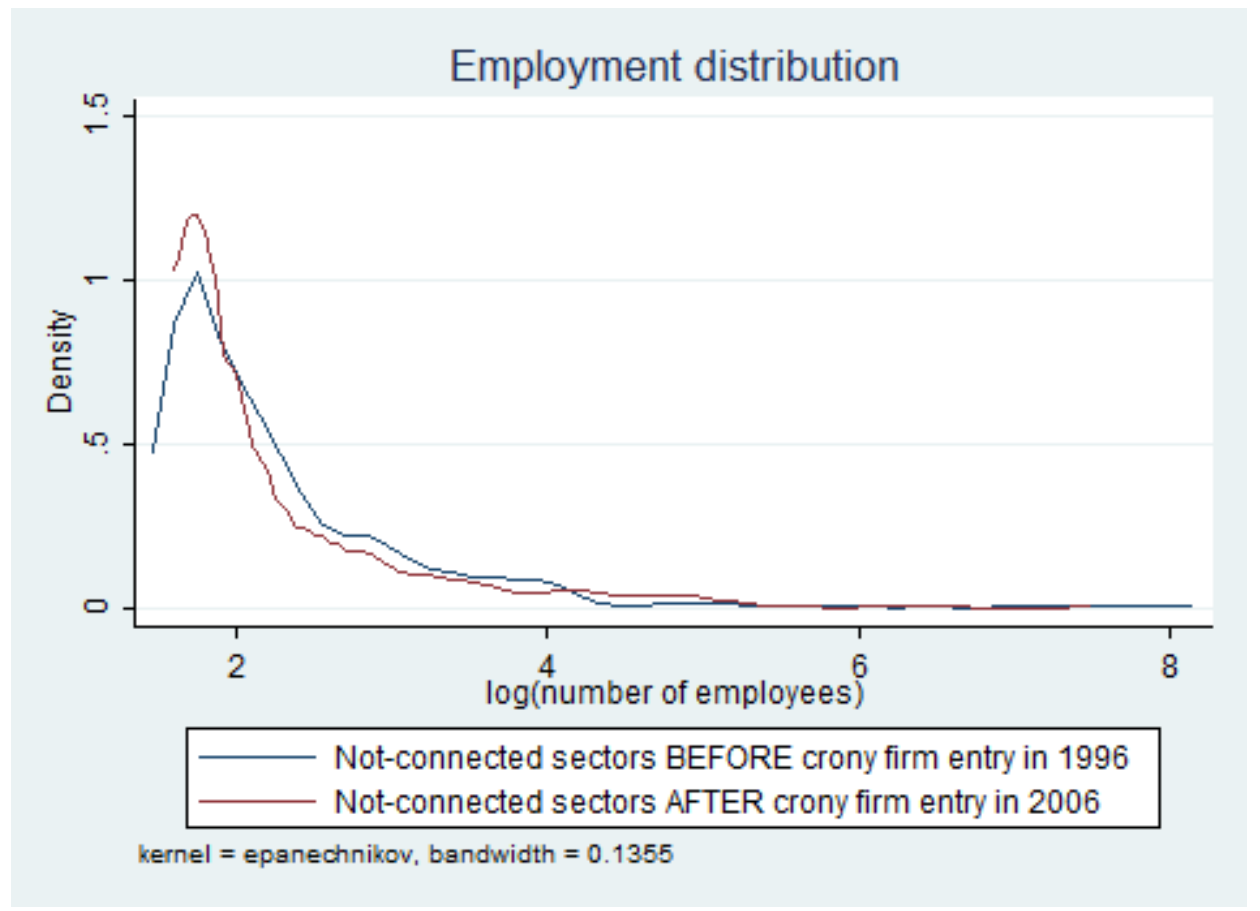

Source: Establishment census data including over 2 million firms in all non-agriculture, non-government sectors in 1996 and 2006 and sample of politically connected firms.

\section{Conclusions}

The wealth of findings reported here contributes to a deeper understanding of the economic consequences of cronyism, shedding light on why the phenomenon could also have significant political consequences in countries ranging from Indonesia to Tunisia. In the Middle East, for example, the rate of job creation in the private sector has failed to keep up with the rate at which new (young) workers have entered the job market, a fact that many have linked to the Arab Spring uprisings. Tepid job creation has also shown the limits of apparently significant market reforms that countries in the region adopted over the past ten years. One hypothesis that explains slow job creation, despite the relaxation of many formal, de jure regulatory and legal obstacles to private sector activity, is that "crony capitalism" has circumvented market reforms and continued to stifle competition, innovation, and job creation. We investigate this hypothesis with data from Egypt.

47 Hussain and Schiffbauer (2014) find that firm productivity are the main driver of employment growth in Egypt (using establishment census data). In particular, they show that manufacturing firms with higher initial productivity levels experience higher employment growth over the subsequent five years after controlling for sector specific effects and other firm characteristics. 
Additional work is needed to fully evaluate the macro-economic impact of cronyism and to predict how the Egyptian economy would have performed in the absence of cronyism. For instance, we would like to better evaluate the impact of political connections on unconnected sectors: did connected sectors weaken forward and backward linkages with unconnected firms, thereby exacerbating negative effects on aggregate growth (Jones, 2011)?

One implication of our results is to cast doubt on the feasibility of industrial policy under a closed political system. While this was successful in other parts of the world, it has not worked in Egypt nor in Tunisia (Rijkers et al, 2014). Industrial policies which are seen by many analysts as an essential part of a successful development drive in the Middle East, in parts to offset the over-valuation of the exchange rates introduced by oil and remittances revenues, cannot work effectively in environments dominated by rent-seeking.

We have not focused in this paper on the broader political-economy of cronyism - in particular, on the services that connected firms supplied to the regime in exchange for regulatory and fiscal privileges. This is also an important subject for future research. Similarly, we have not discussed the implications of cronyism for income inequality, another important driver of the Arab Spring Uprisings - the regime of cronyism must have led to the emergence of a very rich one percent. Moreover, the slow growth of the formal private sector must have exacerbated the prevalent labor market dualism in Egypt, increasing the inequality of opportunities in the labor markets (Assaad 2013). 


\section{References}

Abdel-Latif, Abla, and Jeffrey Nugent (2010). "A Quiz on the net benefits of trade creation and trade diversion in the QIZs of Jordan and Egypt." Economic Research Forum Working Paper no. 514.

Acemoglu, Daron, Tarek Hassan and Ahmed Tahoun (2014). "The Power of the Street Evidence from Egypt's Arab Spring.” NBER Working Paper No. 20665.

Aghion, P., Blundell, R., Griffith, R., Howitt, P., \& Prantl, S. (2009). “The effects of entry on incumbent innovation and productivity." The Review of Economics and Statistics 91(1): 20-32.

Aghion, Philippe, et al. (2001) "Competition, imitation and growth with step-by-step innovation." The Review of Economic Studies 68(3): 467-492.

Ahram Online. Various issues. http://english.ahram.org.eg.

Alley, April Longley (2010). "The Rules of the Game: Unpacking Patronage Politics in Yemen." Middle East Journal 64(3):385-409.

Boubakri, N., Cosset, J.C., Saffar, W. (2008). "Politically connected firms: an international event study." Unpublished working paper. HEC Montreal.

Bertrand, M., Kramaraz, F., Schoar, A., Thesmar, D. (2007). "Politicians, firms and the political business cycle: evidence from France." Unpublished working paper, University of Chicago.

Chekir, Hamouda, and Ishac Diwan (2015). "Crony Capitalism in Egypt." Journal of Globalization and Development. ISSN (Online) 1948-1837.

Chekir, Hamouda and Claude Menard (2012). "Barriers to Private Firm Dynamism in Tunisia: a Qualitative Approach.” World Bank mimeo, 2012.

Cull, Robert, and Lixin Colin Xu (2005). "Institutions, ownership, and finance: the determinants of profit reinvestment among Chinese firms." Journal of Financial Economics 77(1): 117-146.

Demmelhuber, T. and S. Roll (2007). "Maintenance of Domination in Egypt: The Role of Reforms and Economic Oligarchs.” Stiftung Wissenschaft und Politik (SWP), Deutsches Institut für Internationale Politik und Sicherheit.

Faccio, M. (2010). "Differences between Politically Connected and Nonconnected Firms: A CrossCountry Analysis." Financial Management 39, 905-928.

Faccio, M. (2007). "Politically connected firms." American Economic Review 96:369-386.

Faccio, M., R. Masulis and J.J. McConnell (2006). "Political connections and corporate bailouts." Journal of Finance 61: 2597-2635.

Ferguson, T. and H.-J. Voth (2008). "Betting on Hitler - The Value of Political Connections in Nazi Germany." Quarterly Journal of Economics 123: 101-137.

Fisman, Raymond (2001). "Estimating the Value of Political Connections." American Economic Review 91: 1095-1102.

Goldman, E., J. Rocholl, and J. So (2008). "Political Connections and the Allocation of Procurement Contracts.” Indiana University Working Paper. 
Haber, Stephen and Noel Maurer (2007). "Related Lending and Economic Performance: Evidence from Mexico." The Journal of Economic History 67: 551-581.

Haddad, Bassam (2012). Business Networks in Syria: The Political Economy of Authoritarian Resilience. Stanford, CA: Stanford University Press.

Hallward-Driemeier, Mary, Gita Khun-Jush, and Lant Pritchett (2010). "Deals versus Rules: Policy Implementation Uncertainty and Why Firms Hate It." National Bureau of Economic Research,. w16001.

Henry, Clement Moore, and Robert Springborg (2010). Globalization and the Politics of Development in the Middle East. Vol. 1. Cambridge: Cambridge University Press.

Heydemann, S., ed. (2014). Networks of Privilege: Rethinking the Politics of Economic Reform in the Middle East. New York: Palgrave Macmillan.

Hussain, Sahar and Marc Schiffbauer (2014). "Firm dynamics and job creation in Egypt.” World Bank, mimeo.

Imam, Patrick A., and Davina F. Jacobs (2007). "Effect of Corruption on Tax Revenues in the Middle East.” IMF Working Paper 07/270. Washington, D.C.: International Monetary Fund.

Johnson, S., Mitton, T. (2003). "Cronyism and capital controls: evidence from Malaysia." Journal of Financial Economics 67: 351-382.

Jones, Charles I. (2011). "Intermediate goods and weak links in the theory of economic development." American Economic Journal: Macroeconomics, 3:1-28.

Kienle, Eberhard (2004). "Reconciling Privilege and Reform." In Networks of Privilege: Rethinking the Politics of Economic Reform in the Middle East, edited by S. Heydemann. New York: Palgrave Macmillan. 281-96.

Khwaja, A.I., Mian, A. (2005). "Do lenders favor politically connected firms? Rent provision in an emerging financial market." Quarterly Journal of Economics 120, 1371-1411.

King, Stephen Juan (2009). The new authoritarianism in the Middle East and North Africa. Bloomington: Indiana University Press.

Kroszner, R.S. and T. Stratmann, 1998. "Interest Group Competition and the Organization of Congress: Theory and Evidence from Financial Services' Political Action Committees.” American Economic Review 88: 1163-1188.

Leuz, C., Oberholzer-Gee, F. (2006). "Political relationships, global financing, and corporate transparency: evidence from Indonesia." Journal of Financial Economics 81: 411-439.

Loewe, Markus (2013). “Industrial Policy in Egypt 2004-2011.” DIE Discussion Paper 13/2013, Deutsches Institut fuer Entwicklungspolitik, Bonn.

Malouche, Mariem, José-Daniel Reyes, and Amir Fouad (2013). "New Database of Nontariff Measures Makes Trade Policy More Transparent.”World Bank, mimeo.

Owen, Roger (2004). State, power and politics in the making of the modern Middle East. Routledge.

Ramalho, Rita. (2003). “The Effects of Anti-Corruption Campaign: Evidence from the 1992 Presidential Impeachment in Brazil.” M.I.T. Working Paper. 
Rijkers, Bob, Caroline Freund, and Antonio Nucifora (2014). "The Perils of Industrial Policy: Evidence from Tunisia." mimeo, the World Bank.

Roberts, B.E. (1990). "A Dead Senator Tells No Lies: Seniority and the Distribution of Federal Benefits." American Journal of Political Science 34: 31-58.

Roll, Steven (2010). "Finance Matters!' The Influence of Financial Sector Reforms on the Development of the Entrepreneurial Elite in Egypt." Mediterranean Politics 15:349-370.

Sfakianakis, John (2004). “The Whales of the Nile: Networks, Businessmen and Bureaucrats during the Era of Privatization in Egypt." In Networks of Privilege: Rethinking the Politics of Economic Reform in the Middle East, edited by S. Heydemann. New York: Palgrave Macmillan.

Tlemcani, Rachid (1999). Etat, Bazar, et Globalisation: L'Aventure de l'Infitah en Algerie. Algiers: Les Editions El Hikma.

UNIDO (2010). “Compilation of Energy Statistics for Economic Analysis.” Development Policy and Strategic Research Branch Working Paper 01/2010, UNIDO, Vienna.

World Bank 2009. From Privilege to Competition: Unlocking Private-Led Growth in the Middle East and North Africa, Washington, D.C.: World Bank.

World Bank, 2014. Jobs or Privileges: Unleashing the emloyment potential of the Middle East and North Africa, Washington, DC: World Bank. 


\section{Appendix}

Table A1: Number of politically connected firms by economic sectors

\begin{tabular}{l|ccc} 
& $\begin{array}{c}\text { Politically connected } \\
\text { CEO }\end{array}$ & $\begin{array}{c}\text { Politically connected } \\
\text { owner }\end{array}$ & $\begin{array}{c}\text { Any type of } \\
\text { politically connected } \\
\text { firm }\end{array}$ \\
\hline Mining & 0 & 2 & 12 \\
Manufacturing & 26 & 164 & 193 \\
Food \& beverages & 1 & 16 & 33 \\
Textiles \& clothing & 3 & 14 & 22 \\
Chemicals & 0 & 10 & 15 \\
Pharmaceuticals & 0 & 2 & 13 \\
Base metals & 5 & 16 & 19 \\
Machinery \& transport & 4 & 18 & 27 \\
Other manufacturing & 5 & 49 & 64 \\
Utilities & 0 & 10 & 18 \\
Construction & 8 & 29 & 36 \\
Services & 45 & 288 & 388 \\
Wholesale trade & 8 & 65 & 91 \\
Retail trade & 0 & 18 & 25 \\
Transport & 0 & 9 & 13 \\
Hotels \& restaurants & 7 & 35 & 43 \\
Finance & 11 & 38 & 53 \\
Real estate & 4 & 18 & 25 \\
Business services & 7 & 75 & 103 \\
Travel \& tour operators & 1 & 7 & 10
\end{tabular}

Note: The total number of any politically connected firms is 647 since several connected firms operate in more than one 4-digit sector. 
Table A2: UN classification of energy-intensive manufacturing sectors

\begin{tabular}{|ll|}
\hline $\begin{array}{l}\text { Intensity of Energy } \\
\text { Consumption }\end{array}$ & Industry \\
\hline High & $\begin{array}{l}\text { Manufacture of textiles, Paper and paper products, Coke and refined } \\
\text { petroleum products, Chemical products, Non-metallic mineral products, } \\
\text { Manufacture of basic metals }\end{array}$ \\
Moderate & $\begin{array}{l}\text { Food products and beverages, Wearing apparel, dressing and dyeing, } \\
\text { Manufacture of leather products, Wood and wood products, Printing and } \\
\text { publishing, Rubber and plastic products, Fabricated metal products }\end{array}$ \\
& $\begin{array}{l}\text { Tobacco products, Machinery and equipment n.e.c., Office, accounting and } \\
\text { computing machinery, Electrical machinery and apparatus, n.e.c., Radio, } \\
\text { TV and communication equipment, Medical, precision and optical } \\
\text { instruments, Motor vehicles, trailers and semi-trailers, Other transport } \\
\text { equipment, Furniture and other manufacturing n.e.c., Recycling. }\end{array}$ \\
\hline
\end{tabular}

Source: UNIDO (2010).

Table A3: Descriptive statistics WBES among sectors with at least one politically connected firm versus sectors with zero connected firms by types of connection

\begin{tabular}{|c|c|c|c|c|c|c|}
\hline & $\begin{array}{c}\text { Sectors } \\
\text { with PC } \\
\text { CEOs }\end{array}$ & $\begin{array}{c}\text { All other } \\
\text { sectors }\end{array}$ & $\begin{array}{c}\text { Sectors } \\
\text { with PC } \\
\text { owners }\end{array}$ & $\begin{array}{c}\text { All other } \\
\text { sectors }\end{array}$ & $\begin{array}{c}\text { Sectors } \\
\text { with any } \\
\text { PC firm }\end{array}$ & $\begin{array}{c}\text { All other } \\
\text { sectors }\end{array}$ \\
\hline Share of firms acquired Land from Government & $48 \%$ & $37 \%$ & $44 \%$ & $33 \%$ & $44 \%$ & $30 \%$ \\
\hline Share of firms in Industrial City & $47 \%$ & $36 \%$ & $42 \%$ & $33 \%$ & $41 \%$ & $34 \%$ \\
\hline Share of firms with Bank Loan & $21 \%$ & $17 \%$ & $19 \%$ & $17 \%$ & $19 \%$ & $13 \%$ \\
\hline Waiting days for construction permit & 595 & 642 & 608 & 681 & 610 & 696 \\
\hline $\mathrm{CoV}$ (waiting days construction permit) & 0.56 & 0.45 & 0.54 & 0.33 & 0.53 & 0.30 \\
\hline
\end{tabular}

Source: WBES. 
Table A4: Entry of connected firms from 1997-2006 into initially unconnected sectors

\begin{tabular}{|c|c|c|}
\hline $\begin{array}{c}\text { ISIC Rev. } 3.1 \\
\text { 4-digit }\end{array}$ & Sector name 4-digit & $\begin{array}{c}\text { Connected } \\
\text { entrants }\end{array}$ \\
\hline 1410 & Quarrying of stone, sand \& clay & 2 \\
\hline 1429 & Other mining \& quarrying n.e.c. & 2 \\
\hline 1551 & Distilling, rectifying, blending of spirits & 1 \\
\hline 1552 & Manufacture of wines & 1 \\
\hline 1553 & Manufacture of malt liquors \& malt & 1 \\
\hline 1554 & Manufacture of soft drinks \& mineral water & 1 \\
\hline 2412 & Manufacture of fertilizers & 4 \\
\hline 2720 & Manufacture of basic precious metals & 1 \\
\hline 3140 & Manufacture of primary cells \& batteries & 1 \\
\hline 3230 & Manufacture of television \& radio receivers & 3 \\
\hline 3691 & Manufacture of jewelry \& related articles & 1 \\
\hline 3710 & Recycling of metal waste and scrap & 1 \\
\hline 3720 & Recycling of non-metal waste and scrap & 1 \\
\hline 4010 & Electricity production, transmission \& distribution & 3 \\
\hline 4020 & Manufacture \& distribution of gas & 4 \\
\hline 4100 & Collection, purification \& distribution of water & 1 \\
\hline 5131 & Wholesale of textiles, clothing \& footwear & 1 \\
\hline 5141 & Wholesale of solid, liquid \& gaseous fuels & 2 \\
\hline 5152 & Wholesale of electronic \& telecommunications parts & 2 \\
\hline 5211 & Retail sale in non-specialized stores with food & 2 \\
\hline 6120 & Inland water transport & 1 \\
\hline 6601 & Life insurance & 1 \\
\hline 7111 & Renting of land transport equipment & 1 \\
\hline 7411 & Legal activities & 1 \\
\hline 7430 & Advertising & 1 \\
\hline 7512 & Regulation of agencies providing health care, education & 1 \\
\hline 7513 & Regulation of operation of business & 1 \\
\hline 9000 & Sewage \& refuse disposal, sanitation & 1 \\
\hline 9211 & Motion picture and video production \& distribution & 1 \\
\hline 9214 & Dramatic arts, music \& other arts activities & 1 \\
\hline 9231 & Library \& archives activities & 1 \\
\hline
\end{tabular}

